\title{
Dinleme Davranışının Müşterinin Satın Alma Niyeti ve Satın Alma Davranışına Etkisi: Seyahat Acentası Satış Temsilcileri Kapsamında Bir Araştırma
}

\author{
Meryem AKOĞLAN KOZAK, Merve DOĞAN*
}

Dinleme Davranışının Müşterinin Satın Alma Niyeti ve The Impact of Listening Behavior on Customer's Satın Alma Davranışına Etkisi: Seyahat Acentası Satış Purchase Intention and Buying Behavior: A Research on Temsilcileri Kapsamında Bir Araştırma the Scope of Travel Agency Sales Representatives

Özet Abstract

Bu araştırmanın amacı, dinleme davranışının bir türü olan aktif The aim of this research is to examine the effect of active empatik dinleme davranışının, satın alma niyeti ve satın alma empathic listening behavior, which is a kind of listening davranışı üzerindeki etkilerini seyahat acentası satışları behavior, on purchase intention and purchase behaviour in the kapsamında incelemektir araştırmanın katılımcıları son $1 \mathrm{yll}$ case of travel agency. The participants of this research is içerisinde herhangi bir acenta ile temasa geçmiş bireylerden composed of individuals who contact with an agent in the past oluşmaktadır. Araştırmanın katılımcıları kolayda örnekleme 1 year. The participants are determined by convenience yöntemiyle belirlenmiş ve veriler anket aracilğıyla toplanmıştır. sampling method and data is collected through questionnaires. Veri toplama sürecinde 300 kişiye anket uygulanmış, kontrol It is applied to 300 participants and 247 survey forms are sorusundan dolayı 247 kişiden elde edilen veriler araştırma subjected to analysis because of the control question. The kapsamında analiz edilmiştir. Araştırmanın bulguları, satış results show that the active empathetic listening behaviour of temsilcisinin aktif empatik dinleme davranışının, müşterinin salesperson, as a perceived by consumer, have a significant and satın alma niyeti ve satın alma davranışı üzerinde pozitif ve positive effect on consumer purchase intention and purchase anlamlı etkilere sahip olduğunu göstermektedir. behaviour.

4nahtar Kelimeler: Aktif Empatik Dinleme, Dinleme, Satış Temsilcisi, Satın Alma Niyeti, Satın Alma Davranışı, Seyahat Acentası
Key Words: Active Empathetic Listening, Listening, Salesperson, Purchase Intention, Purchase Behaviour, Travel Agency

\section{Giriş}

İletişim, hem teorik hem de uygulama boyutları ile insan yaşamının her alanında var olan bir olgudur. İnsanlar için iletişim yaşamsal bir eylemdir. Öyle ki insanlar var olmak, yaşamlarını sürdürmek, haberleşmek, paylaşmak, etkilemek, yönlendirmek gibi temel amaçlara yönelik olarak birbirleri ile iletişim kurarlar.

* Meryem AKOĞLAN KOZAK, Prof. Dr., Anadolu Üniversitesi, İşletme Fakültesi, Konaklama Bölümü, mkozak@anadolu.edu.tr; Merve DOĞAN, Anadolu Üniversitesi, Sosyal Bilimler Enstitüsü, Turizm İşletmeciliği Doktora Öğrencisi, merve_dogan@anadolu.edu.tr 


\section{Meryem AKOĞLAN KOZAK | Merve DOĞAN}

Iletişimin önemli bir unsusu olan dinleme, insanların belki de en fazla kullandıkları iletişim becerisidir. Tüm insan ilişkilerinin temelinde bulunan iletişim, olumlu insan ilişkileri geliştirebilmenin, daha tatmin edici bir yaşam sürmenin, günümüzün rekabet yoğun iş ortamında rakiplerden farkl-laşmanın, bireysel ve örgütsel alanda başarının ön koşuludur. Doğru iletişim kurma ve sürdürme, diğer insanları anlama ve kendini iyi bir şekilde ifade edebilme, karşılaşılan sorunları öğrenme ve bunları çözebilme edimleri etkili dinleme becerisine sahip olmayı gerektirmektedir. Özellikle iş yaşamında etkili ve iyi dinlemenin olumlu ve faydalı etkileri olabildiği gibi kötü dinlemeler ve dinleme hataları yanlış anlaşılmalarla, kaçırımış iş fırsatlarıyla, zaman ve para kayıplarıyla sonuçlanabilmektedir (Digaetani, 1980). Bu etkilerinden dolayı dinleme konusu pazarlama, satıs gibi insan ilişkilerinin yoğun yaşandığı işletme alanlarıyla ilişkilendirilerek pek çok araştırmacı tarafından ele alınmaktadır.

İnsan ilişkilerinin çok önemli olduğu pazarlama ve satış alanlarında, tüketicilerin istek ve ihtiyaçlarını anlamada, müşterileri elde tutma ve yeni müşteriler kazanmada, en önemlisi uzun dönemli kârı ilişkiler geliştirmede iletişimin dolayısıyla da iletişime geçilen kimseyi etkili şekilde dinlemenin rolü oldukça önemlidir. Özellikle turizm gibi hizmet pazarlarında hizmetin özelliklerinden kaynaklı olarak müşterilerle iletişim ve etkileşim ile uzun dönemli ilişkiler daha önemli olduğundan, satış temsilcisinin dinleme becerilerinin önemli olduğunu düşündürmektedir. Literatürden hareketle satış temsilcisinin etkili dinleme davranışı ile müşteri satın alma niyeti ve satın alma davranışııın birbirleriyle ilişkili konular olabileceği, bu bağlamda satış temsilcisinin aktif empatik dinleme becerilerinin müşteri satın alma niyeti ve davranışı üzerinde olumlu etkisi olabileceği düşünülmektedir. Diğer sektörlerde farkı bulguların yer aldığı bu öngörü ile ilgili olarak turizm sektörü veya seyahat acenteleri kapsamında gerçekleştirilmiş herhangi bir araştırma bulgusuna rastlanamamışır. Seyahat acentası satı̧ temsilcisinin dinleme becerilerinin müşteri satın alma niyeti ve satın alma davranışları üzerindeki önemini gösterebilmek amacıyla gerçekleştirilen bu araştırmanın, acenta temsilcileri kadar seyahat hizmeti alan kişiler açıından da önemli olacağı düşünülmektedir. Iletişim ve dinleme becerilerinin insan ilişkileri geliş̧tirme ve sürdürmedeki rolü bu çalışmanın önemli bir gerekçesidir. Ayrıca, geçmişte iletişim, dinleme ve satış ile ilgili yapılmış çalışmalardan hareketle satış temsilcisinin etkili dinleme ve aktif empatik dinleme davranışlarının müşterinin satın alma kararlarına olumlu yönde etki eden unsurlar olduğu düşünülmektedir. Satış temsilcileri, işletme ve müşteriler arasında bir bağlantı noktası olup iletişimi sağlamada başrol oynadığından, etkili dinleme becerilerine sahip olmaları beklenmektedir.

Araştırma neticesinde elde edilen sonuçların, dinleme davranışının bir türü olan aktif empatik dinlemenin özellikle seyahat ve turizm alanındaki satış ilişkilerindeki önemini anlamada, mevcut ve potansiyel satışları artırmada, müşterileri ikna etmedeki rolünü belirlemeye yönelik katkılar sağlayacağı düşünülmektedir. Bununla birlikte, satıs temsilcisinin dinleme becerilerinin müşteri satın alma niyeti ve satın alma davranışı üzerinde olumlu yönde etkileri olabileceği ve buradan hareketle araştırmanın "Sebepli Eylem Teorisi”ne de bir katkı sağlayacağı öngörülmektedir. 


\section{Dinleme ve Dinleme Türleri}

İletişim olayı genellikle okuma, yazma, konuşma ve dinleme olmak üzere dört temel beceri ile gerçekleştirilmektedir. Bunlar arasında yer alan dinleme yeteneği doğuştan gelen bir dürtü olup iletişimin temel becerilerinden biridir (Brownell, 1990, s.401). Dinlemeyi bir yetenek olarak düşündüğümüzde bazı insanlar bu konuda başarılı bazıları ise başarısız olmaktadır. Bu konuda başarılı olanların dikkatli bir dinleme yeteneği ile ayrıntılara dikkat etme, resmi karşı tarafın perspektifinden görme, doğru şekilde karşılık verme ve yapıcı olma gibi özelliklere sahip olması beklenmektedir. Genel olarak insanlar tüm gün boyunca çoğu zaman farkında olmadan birçok şeyi dinlemektedirler. Bireylerin gün içerisinde vakitlerinin yaklaşık \%45-\%63'ünü dinleme ile geçirdikleri belirtilmektedir (Digaetani, 1980, s.40). Yirmi dört saatlik bir günün uykuda geçen kısmını bir kenara ayııırsak bu oran, dinleme konusuna hem gündelik ve profesyonel hayatta hem de araştırmalarda daha fazla önem verilmesi gerektiğini düşündürmektedir. Dinleme insan hayatında bu kadar yer tutmasına karşın, özellikle insan ilişkilerinin oldukça önemli olduğu hizmetlerin pazarlanması ve satışı alanlarında bu konuya ilişkin yeterli çalışmaya rastlanmamıştır.

Dinleme kavramına değinmeden evvel öncelikle dinleme ve duyma kavramlarını birbirinden ayırmak gereklidir. Çoğu zaman dinleme ve duyma birbirine karıştııılmakta, birbirleri yerine kullanılmaktadır. Ancak duyma, irade dışı kulağa giden her türlü ses unsuru ve doğuştan gelen biyolojik bir fonksiyonken; dinleme kişinin tercihine bağlı olarak seçilmiş seslerin bütünü ve sonradan kazanılan ve geliştirilebilen bir yetenektir (Boe, 2012). Kısaca, duyma fiziksel ve biyolojik bir olaydır. Bu ayırımdan anlaşılacağı üzere dinleme ve duyma aynı kavramlar değildir. Duyma için dinlemenin gerçekleşmesinde gerekli bir unsurdur demek yanlış olmayacaktır. Diğer bir deyişle, duyma dinleme sürecinin başlamasında ve sürdürülmesinde başrol oyuncusudur. Dinleme ve duymanın daha iyi ayırt edilebilmesi için dinlemenin bazı tanımlarına yer vermek uygun olacaktır. Gross (1982) dinlemeyi “iş̧itme, anlamın belirlenmesi, eleştirel analiz ve sözlü mesajın bir değer kazanması sürecidir" şeklinde tanımlayarak işitmenin dinlemeyle aynı şey olmadığını, dinlemenin bir aşaması olduğunu ifade etmektedir. Dinleme, anlamaya dayanan birçok işlemin bir arada ve birbirini tamamlar bir şekilde gerçekleştirildiği bir edimdir. Belirli bir düzende akışa sahip eylemler bütünü olup fiziksel, duygusal ve bilişsel unsurları kapsayan karmaşık eylemlerden oluşmaktadır (Brownell, 1985, s.40). Dinleme konusu sosyal bilimlerde pek çok alanda irdelenmiş ve araştırılmış bir konudur. Literatürde farklı alanlarda yapılmış farklı dinleme tanımları bulunmaktadır. Ancak bu araştırmada daha çok satış, pazarlama ve işletme literatüründe yer alan tanımlamalara yer verilmiştir.

Dinleme en genel ifadeyle, duyulan seslere anlam verilmesidir (Odabaşı, 1997, s.44). Taraflara ulaşan anlamlandırılmamış sesler ancak yukarıda sözü geçen duyma kavramı kapsamında değerlendirilebilmektedir. Anlamlandırımamış sesler ile iletişimin başlaması ya da sürdürülmesi olası değildir. Çalışmanın konusu ve kapsamıyla ilgili olarak örgütsel ortam bağlamında yapılmış bir dinleme tanımına yer vermek gerekirse " Dinleme, dikkat, sözlü ve sözsüz davranışlar, algılanan tutumlar, hafıza ve davranışsal yanıtları içeren, birbiriyle ilişkili faaliyetler dizisidir." (Lewis ve Reinsch, 1988, s.50). Tanımdaki sözsüz davranışlar kavramına dikkat çekmekte fayda vardır. Çünkü dinleme sadece kulağa gelen seslerle ilgili değildir. Aynı zamanda jest ve mimiklerle aktarılan sözsüz mesaj- 


\section{Meryem AKOĞLAN KOZAK | Merve DOĞAN}

lara da dikkat etmeyi gerektirmektedir. Kişinin beden dili altında söze dökmediği bazı ipuçları yatabilmektedir. Etkili bir dinleyicinin bu gizil mesajları yakalayabilme olaslığı fazla olmaktadır. Yine araştırma konusuyla ilintili olarak satış bağlamında yapılmış bir diğer tanıma göre dinleme, mevcut ya da potansiyel müşterilerin sözlü ve sözsüz mesajlarının etkin bir şekilde alglanması, yorumlanması, değerlendirilmesi ve mesajlara yanıt verilmesi olarak tanımlanmaktadır (Castleberry ve Shepherd, 1993, s.36). Literatürdeki tanımlardan hareketle dinleme için bir tanım yapmak gerekirse, "Sözlü ve sözsüz uyarıları fiziksel olarak algılamayı, zihinsel bir süreçten geçirerek onlara anlamlar yüklemeyi ve algılanan uyarılara atfedilen anlamlar bağlamında sözlü ve sözsüz uygun yanıtlar vermeyi gerektiren aktif bir süreç, karmaşık aktivitelerden oluşan faaliyetler bütünüdür".

Bu tanımlar ve burada yer verilmeyen diğer tanımlar dinlemenin bilişsel, duygusal ve davranışsal unsurlar içeren karmaşık bir süreç olduğunu göstermektedir. Diğer bir söylemle, dinleme hem sözel hem de sözel olmayan mesajların alınıp işlendiği faaliyetler dizisidir. Satış ve pazarlama bağlamında yapılan çalışmalar incelendiğinde, dinleme sürecinin çeşitli kııımlara ayrıldığı ve bazı boyutlar oluşturulduğu görülmektedir. Çoğu birbirine benzer olmakla birlikte dinlemenin genellikle üç ya da dört boyutlu bir yapı olarak ele alındığı dikkat çekmektedir. Örneğin, Gross (1982) dinlemenin algılama, değerlendirme, hatıllama bileşenlerinden oluştuğunu ifade etmektedir. Bu ayırım hafıza, hatırlama gibi unsurların dinlemedeki davranışal aşamanın meydana gelmesinde gerekli olduğunu göstermektedir. Satış, pazarlama ve turizm bağlamında düşünülürse, bir satış temsilcinsin müşteriye ait önemli bilgileri hatırlaması, müşteriyi memnun edebilmekte ve markaya, ürüne, işletmeye olan bağllı̆ıına olumlu yansıyabilmektedir. Dinlemenin boyutları için diğer bir ayırım Brownell (1985) tarafindan yapılmıştır. Araştırmacıya göre dinleme, işitme, anlama, yorumlama, değerlendirme, hatıllatma ve yanıt verme aşamalarından meydana gelmektedir. Burada dinleme sürecinin biraz daha ayrıntılı şekilde boyutlandırıldığını ve hatırlatmanın bir boyut olarak yer aldığını görmek mümkündür. Dinlemenin boyutlarını daha genel olarak ele alan ve pek çok çalışmada karşımıza çıkan bir diğer bir boyutlandırma girişimi Castleberry ve Shepherd (1993) tarafından yapıımışır. Onlar dinlemenin alglama, yorumlama, değerlendirme ve yanıt verme boyutlarından oluştuğunu ifade etmektedir. Diğer bazı ayııımlarda da birlikte yer alan yorumlama ve değerlendirme boyutları aslında tek bir boyut olarak da ele alınabilmektedir. Çünkü her ikisi de ilk aşamada algılanan seslerin zihinsel olarak işlenmesi süreciyle eş değer olarak düşünülebilmektedir. Ruyter ve Wetzels (2000) ise dinlemeyi bu düşünce bağlamında boyutlara ayırmaktadır. Onlar dinlemenin boyutlarını dikkat, anlayış ve yanıt verme olarak kabul etmektedir. Buradaki anlayış boyutu aslında değerlendirme ve yorumlamayı da içeren zihinsel bir boyuttur. Benzer şekilde bir başka araştırmacı da dinleme sürecinin, mesajın algılanması, değerlendirilmesi ve mesaja yanıt verilmesi boyutlarından meydana geldiğini ifade etmektedir. Genel olarak dinleme sürecinin algılama boyutu ile başladığı varsayılmaktadır. Algılama, sözlü ve sözsüz uyarıları almayı ve mesaja katılmayı ifade etmektedir. Değerlendirme boyutu, dinleyicinin zihninde algıladığı mesaja yönelik olarak oluşan aktiviteleri ifade etmektedir. Bu boyut bilişseldir ve mesajı alan kişinin mesaja anlam ve değer yüklemesi gerçekleştirmesini ifade etmektedir (Ramsey ve Sohi, 1997, s.128). Fiziksel olarak her insan aynı sesi duymakta, ancak zihinde işleme süreci ve buna bağı anlamlandırma herkese göre farkllık gösterebilmektedir. Anlam nadiren tamamen değişmemektedir. Satış bağlamında dinlemede özellikle ilk 
iki boyutun müşteri isteklerini ve intiyaçlarını doğru bir şekilde anlamada, onları tatmin etmede önemli role sahip olduğunu söylemek mümkündür. Fiziksel olarak doğru bir şekilde algılanan, müşteri istek ve ihtiyaçları doğrultusunda zihinsel olarak işlenen mesajlara verilen yanıtların müşterileri tatmin etmesi daha olası olduğu düşünülmektedir. Bu noktada yanıt verme boyutuna değinmek gerekirse; yanıt verme dinleyicinin konuşan kişiden aldığı ve zihinsel süreçte anlamlandırdığı mesajlara uygun şekilde geri bildirim yapmasını ifade etmektedir (Bergeron ve Laroche, 2009, s.9). Geri bildirim sürecinde sözlü mesajlar kadar sözsüz mesajlar da önem taşımaktadır. Bu aşamada dikkat edilmesi gereken, sözlü ve sözsüz mesajlar arasında uyum olmasıdır. Eğer sözle ifade edilenler, yüz, el, kol ya da diğer beden hareketleriyle zıtlık oluşturuyorsa karşı taraf bu duruma olumsuz anlamlar yükleyebilmekte, iletişim ve ilişkinin sağıkıı biçimde sürdürülmesi önünde engel oluşturabilmektedir.

Literatürden hareketle dinleme hangi boyutlandırma açısından ele alınırsa alınsın dinleme süreci ilk olarak sözsel seslerin ve sözlü olmayan mesajların fiziksel olarak algılanması ile yani duyu organları aracılığı ile algılanmasıyla başlamaktadır. Daha sonra duyu organları tarafından algılanan mesajlar zihinsel bir süreçten geçirilerek algılanan mesajlara anlamlar yüklenmekte ve dinleyici mesajlara atfettiği anlamları zihinsel olarak değerlendirmektedir. Son olarak dinleyicinin anlamlandırdığı mesajları yorumlayarak uygun bir yanıt vermesi ile dinleme süreci gerçekleşmiş olmaktadır. Hangi sektörde olursa olsun bir satış temsilcisinin, etkili dinleyici olarak algılanabilmesi için dinlemenin tüm boyutları ile meşgul olması gerekmektedir (Ramsey ve Sohi, 1997). Dinleme hem sosyal yaşamda hem de profesyonel yaşamda özellikle bilginin transferi açısından önemli bir rol oynamaktadır. Dinleme, günlük sosyal etkileşimlerde doğru anlamak ve anlaşılmak açısından kritik bir öneme sahipken, iş hayatında da oldukça önemli olup kişilerin başarı ve başarısızlıkları arasındaki farkı oluşturabilmektedir (Michael, 2000).

Dinleme çeşitli türlerde olabilmekte ve bu türler konuya, kişiye ya da kişilere, zamana ve ortama göre farklıık gösterebilmektedir. Literatürde dinleme türleriyle ilgili çeşitli sınıflandırmalar yapılmaktadır. Örneğin, aktif ve pasif dinleme, eleştirel ve eleştirel olmayan dinleme, yüzeysel ve derin dinleme, empatik ve objektif dinleme, bilgilendirici dinleme, ilişkisel dinleme, takdir edici dinleme, tanımlayıc dinleme, anlamak için dinleme, değerlendirmeli dinleme, aktif empatik dinleme, marjinal dinleme, sosyal dinleme ve kritik dinleme bunlardan bazılarıdır. Her bir dinleme türünün kendine özgü özellikleri ve amaçları olmakla birlikte, temelde dinlemeyi iyi dinleme ve kötü dinleme diye ayırmak yanlış olmayacaktır. Çünkü dinleme ya etkili ve başarıı bir dinlemedir ya da kötü, başarısız bir dinlemedir. Hangi ortamda ve kimle olursa olsun önemli olan etkin, dikkatli ve başarılı bir dinleme yapabilmektir. Etkili dinleme belirli noktalara dikkat edilerek empatik, derin, değerlendirmeli gibi isimler almakta ve farklı dinleme türleri olarak karşımıza çıkmaktadır. Dinleme türleri arasında en aşina olduğumuz türler aktif ve pasif dinleme türleridir. Satış bağlamında dinleme literatürü incelendiğinde de bu türlerden yaygın olarak bahsedildiği görülmektedir. Bu çalışma kapsamında ele alınacak aktif empatik dinleme türü aktif dinleme türü içerisinde açıklanmaya çalışılacaktır. 


\section{Meryem AKOĞLAN KOZAK | Merve DOĞAN}

\subsection{Pasif Dinleme}

Pasif dinleme isminden de anlaşılacağı gibi dinleyicinin karşısındaki kişiyi yüzeysel bir dikkatle dinlediği ve dinleme sürecine aktif bir şekilde katılmadığı dinleme türüdür. Diğer bir deyişle, dinleyicinin karşısındaki kişiye katkıda bulunmadan dinlemesidir. Dinleyen kişi, konuşma bittiğinde ne söyleyeceğini ya da başka bir konuyu düşünmektedir. Dolayısıyla, dinleme sürecine etkin bir şekilde dâhil olamamaktadır (Gürel ve Tat, 2012, s.27). Bir sonraki bölümde bahsedilecek olan aktif dinlemede dinleyici konuşanın hislerini, gerçekleri ve ayrıntıları yakalamaya çalışırken pasif bir dinleyici ise ayırım yapmadan dinlemektedir. Dinleyici konuşan kişiye odaklanmadığı için isim, konunun ana noktası gibi önemli hususları unutabilmektedir. Bu durum da iletişimin kalitesini olumsuz etkilemektedir. Bunun sebebi, pasif dinlemede, seslerin kulağa akan mesajlar şeklinde ulaşması ve mesajlara sınırlı dikkat verilmesidir. Bunun sonucunda çoğu zaman dinlenenler kalıcı olmamaktadır (Powell, 1983). Hatırlama hususunun önemli olduğu satış ilişkilerinde, bir satış temsilcisini pasif dinlemeci olması istenmeyecektir. Çünkü pasif dinlemede mesajlar kalıcı olmadığından dinleyici konuyu tam olarak kavrayamaz, bu nedenle etkili bir dinlemenin olmazsa olmazı olan doğru şekilde karşlık vermeyi gerçekleştirememektedir. Anlaşılacağı üzere pasif dinleme, kusurlu bir dinleme türüdür ve genellikle iletişimin etkinliğini düşürdüğünden taraflar arasında arzulanan bir tür olmamaktadır. Pasif dinlemenin çatışmalar, kaybedilen iş fırsatları, bozulan ilişkiler, para ve zaman israfı gibi olumsuz sonuçları olabilmektedir (Bergeron ve Laroche, 2009).

\subsection{Aktif Dinleme ve Aktif Empatik Dinleme}

Aktif dinleme en basit anlamda etkili dinleme demektir. Aktif dinleme karşıdaki kişinin salt ne dediğini işitmekten öte mesajın anlamının ne olduğunu doğru biçimde anlamaktır (Ramsey ve Sohi, 1997, s.128). Aktif dinleme sadece kulakla işitilen mesajları içermeyip aynı zamanda vücut dili, göz teması, duygular, yüz ifadeleri gibi sözsüz mesajları da içermektedir (Comer ve Drollinger, 1999). Diğer bir deyişle, aktif bir dinleme iletişim sırasında hem sözlü hem de sözsüz unsurlara dikkat etmeyi dolayısıyla kulak dışında gözleri de etkin bir şekilde kullanmayı gerektirmektedir. Konuşan kişinin vücut dilini gözlemlemek, kullandığı kelimelerle ses tonunun, duruşunun, jest ve mimiklerinin uyumuna bakmak dinlemenin etkili olmasını sağlamaktadır. Konuşan kişinin söylediklerinin tam olarak ne ifade ettiğini anlayabilmek için enerji, zihinsel çaba, disiplin, irade ve yoğunlaşma gereklidir ki bunlar aktif dinlemeyi destekleyici faktörler olmaktadır (Wert, 1989; Brody, 2001). Aktif dinleyicinin yanıtı da hem sözlü hem de sözsüz unsurlar içermektedir. Bu şekilde karşı tarafın konusuyla ilgilendiği ve sorununu gerçekten dinlediği mesajını vermektedir. Pasif dinlemenin aksine aktif bir dinleyici konuşan kişiyi anlamaya odaklıdır, kişinin hislerini ve gerçekleri anlamaya çalışmaktadır. Aktif dinleme ister iş hayatında ister sosyal hayatta olsun her türlü ilişkideki iletişim sürecinde arzulanan bir dinleme türüdür. Aktif dinleme ile konuşmacı kişinin söyledikleri ilk seferde anlaşılabilmekte ve zaman kazanımı sağlanabilmektedir. Ayrıca, aktif dinleme yanlış anlaşılmalara bağlı mesleki hataları ve kişiler arası problemleri azaltmada faydalı olabilmektedir. Aktif dinlemenin var olduğu bir ortamda dinleyicinin karşısındaki kişi işveren, müşteri, arkadaş, eş ya da karşısındaki her kim ise sonuçtan memnun kalması mümkün olmaktadır. 
Aktif empatik dinleme, aktif dinleme türünün empati ile birleşerek üstün hale gelmiş biçimidir (Drollinger, Comer ve Warrington, 2006, s.162). Literatür incelendiğinde aktif empatik dinlemenin yakın zamanlarda ortaya konmuş bir tür olduğu ve bu türle ilgili yapılmış çalışmaların diğer türlere kıyasla oldukça az olduğu dikkat çekmektedir. Aktif empatik dinlemenin temel görüşü en etkili dinlemenin empati ve aktif dinlemenin bir araya getirilerek yapılacağı görüşüdür (Comer ve Drollinger, 1999). Aktif empatik dinleme kavramını daha iyi anlamak için öncelikle empati kavramına açıklık getirmekte yarar vardır. Empati, bir insanın kendisini karşısındaki insanın yerine koyarak onun duygularını ve düşüncelerini doğru olarak anlaması olarak tanımlanmaktadır (Dökmen, 1997, s.102). Başka bir deyişle empati, diğer kişi ile birlikte hissetme hareketidir. Bir insan empati kurarken kendi düşüncelerini, analizlerini ve işlerini bir kenara koyarak diğer kişiyi anlamaya ve karşısındaki kişiyle birlikte hissetmeye başlamaktadır (Bellous, 2001). Karşıdaki kişinin duygularını, hislerini ve düşüncelerini tam olarak anlayarak bunu ona ifade edebilmek empatiyi içeren dinlemeden geçmektedir ve bu tarz bir dinleme konuşan kişiye anlaşıldığını hissettirmektedir (Gürüz ve Eğinli, 2010). Aktif empatik dinleme sürecini kısaca özetlemek gerekirse, aktif empatik dinlemede dinleyici sözlü ve sözsüz mesajları alarak onları bilişsel olarak işler, mesajlara sözlü ve sözsüz biçıimde yanıt verir ve son olarak kendini müşterinin yerine koyarak sezgisel olarak bunların altında yatan anlamları değerlendirmeye çalışır. Bu süreç, dinleyicinin belirli bir etkileşim sırasında, konuşmacı tarafından algılanan, bilinçli aktif ve duygusal katılımıdır şeklinde de tanımlanabilmektedir (Bodie, 2011, s.278). Aktif empatik dinleyiciler kişisel satış sürecinin her aşamasında diğer dinleyicilere göre daha etkili ve başarılı olmaktadır. Özellikle satış bağlamında satış temsilcilerinin aktif empatik dinleme becerilerinin kişisel satış sürecini kolaylaştırdığı, satış temsilcilerinin performansını arttırdığı, aktif empatik dinleyicilerin kişisel satış sürecinin her aşamasında diğer dinleyicilere göre daha etkili ve başarıı olduklarını ortaya koyan çalışmalar mevcuttur. Bazı araştırmacılar satış temsilcisi ve müşteri arasındaki kişilerarası iletişimin etkili olması için satış elemanı tarafından empatinin zorunlu olduğunu belirtmektedir (Comer ve Drollinger, 1999, s.20).

Önceki bölümde, dinlemenin farklı ayırımlar mevcut olmakla birlikte çok boyutlu bir süreç olduğu belirtilmişti. Aktif empatik dinleme türünü geliştiren araştırmacılar bu tür için geliştirdikleri ölçek neticesinde aktif empatik dinlemenin boyutlarını "algılama, işleme ve yanıt" olarak ele almakta ve aktif empatik dinlemenin bu üç boyut tarafından temsil edilebilir kademeli bir yapı olduğunu ortaya koymaktadırlar (Drollinger vd. 2006, s.163).

Algılama: Algılama dinlemenin temelini oluşmaktadır ve aktif empatik dinleme süreci de algılama ile başlamaktadır. Bu boyut, diğer kişi konuşurken dinleyicinin aktif bir şekilde sürece dâhil olmasını ve o kişiden mevcut tüm bilgileri almasını ifade etmektedir. Bu sadece söz konusu kelimeleri algılamayı değil aynı zamanda mesajın ilişkisel içeriğini de algılamayı ve diğer kişinin duygusal ihtiyaçlarına duyarlı olmayı da içermektedir (Bodie, 2011, s.279). Konuşma esnasında geçen sözlü ipuçları bir mesajın bilişsel içeriğinin büyük bir kısmını taşırken, sözsüz ipuçları ise empatinin sahneye çıktığı duygusal bağlıık ve ilişkiyi yansıtmaktadır. Satış ilişkileri bakımından ele almak gerekirse, sözsüz ipuçları, müşterinin isteklerini anlama ve yerine getirmede özellikle kişisel satışta önemli rol oynamaktadır. Bir müşteri satışla ilgili kaygılarını veya onun için önemli olan kısmı sözel olarak ifade 


\section{Meryem AKOĞLAN KOZAK | Merve DOĞAN}

etmemiş olsa bile aktif empatik dinleme becerisine sahip bir satış̧ı empati aracılığı ile müşterinin ses tonundan, yüz ifadelerinden mesajları alabilecek ve yardımcı olabilecektir.

İ̧̧leme: İşleme boyutu dinleyicinin zihninde yer alan aktiviteleri ifade etmektedir. Diğer bir deyişle, işleme sürecinde alınan mesajlar zihinde organize edilmekte ve anlamlandırılmaktadır. Aktif empatik dinleme sürecinin işleme boyutunda, dinleyici muhatap olunan kişi tarafından üretilmiş yorumları hatırlar, uygun olduğunda önemli noktaların aydınlatılması için sorular sorar ve kişinin konuşmasının farklı bölümlerini bütünleştirmeye çalışı (Bodie, 2011, s.279). İ̧̧leme mesajı alan kişinin mesaja anlam ve değer yüklemesini gerçekleştirdiği aşamadır ve dinleyici bu aşamada mesajin önem derecesini belirlemektedir. İşleme esnasında zihinde, alınan mesajlara yönelik, anlama, yorumlama, değerlendirme ve hatırlama aktiviteleri gerçekleşmektedir (Comer ve Drollinger, 1999, s.16). Dinleyicinin empati yaptığı aşama bu aşamadır demek mümkündür. Çünkü empati zihinsel ve duygusal faaliyetleri içermektedir. Bu faaliyetler sonucunda karşıdan alınan mesajlar anlam kazanmaktadır. Satış açısından bakııdı̆ıında, müşteriyle bir iletişim içinde olan satı̧ temsilcisi aldığı mesajdan hareketle hızlı bir biçimde durumu değerlendirmeli ve mesajda gerçekte ne iletilmek istediğini belirmeye çalışmalıdır. Satış temsilcisi sadece mesaja değil aynı zamanda müşterinin satın alma güdülerine, iletişim tarzına, muhtemel itiraz ve engellere de odaklanmalıdır. Bu da iyi bir gözlem ve empati ile mümkün olabilmektedir. Satıs elemanı müşteri konuşurken onun sözünü kesmeden ve konuyu değiştirmeden dinler ve ne söylediğini anlamak için çaba sarf ederse, konuyla ilgili daha fazla bilgi edinmek için sorular sorarsa, müşteri de söylediklerinin dinlendiğini ve aktif olarak değerlendirildiğini alglayabilecektir. Bu durumda satıı ve müşteri arasındaki dinleme süreci etkin biçimde ilerleyecektir.

Yanıt: Kişilerarası iletişim çift yönlüdür diğer bir deyişle karşılıklı olma özelliği taşımaktadır. Hem dinlemeyi hem de karşılık vermeyi içermektedir. Iletişim süreci içinde karşıdaki kişiyi dinlediğini göstermek ve iletişim sürecinin devamlılı̆ını sağlamak için geri bildirim vermek gereklidir. Yanıt boyutu mesajı alan kişinin, mesaja uygun tepki geliştirdiği ve ilettiği boyuttur, dolayısıyla dinlemenin davranışsal boyutudur. Ayrıca, yanıt boyutu dinleyicinin sorular sorması, algıladıklarını kendi sözcükleriyle ifade etmesi, aynı zamanda baş sallayarak onaylama, yüz ve göz hareketleri gibi sözsüz iletişim unsurlarını da kullanarak aktif bir dikkat göstermesi ile karakterizedir (Bodie, 2011, s.279).

Hem sözel hem de sözel olmayan bu unsurlar, özellikle satış etkileşimlerinde, mesajların taraflar arasında alındığını ve karşılıkı anlayışı kolaylaştııımaya çalışılığını göstermektedir ve iletişimin devamı için tarafları cesaretlendirmektedir (Drollinger vd. 2006, s.164). Yanıt verme aslında bir sorun çözme aşamasıdır ve satış penceresinden bakıldığından önemli bir boyut olduğu düşünülmektedir. Bir satı̧ temsilcisi müşteriden aldığı mesajlara evet/hayır şeklindeki kısa cümlelerden ziyade soruları cevaplamak üzere tam cümleler kullanırsa, konuya uygun cevapları uygun zamanda verirse, müşterinin sorduklarına uygun önerilerde bulunursa, müşteri satış temsilcisinin kendisine cevap vermeye istekli olduğunu hissedebilmektedir. Öte yandan, satı̧ temsilcisi verdiği uygun yanıtlar ile müşterisinin sorununu çözmüş ve ihtiyacını gidermiş olacaktır. 
Özellikle insan ilişkilerinin çok önemli olduğu turizm, pazarlama ve satış alanlarında, tüketicilerin istek ve ihtiyaçlarını anlamada, müşterileri elde tutmada ve yeni müşteriler kazanmada belki de en önemlisi uzun dönemli kârlı ilişkiler geliştirmede, iletişim ve dolayısıyla karşıdakini aktif bir şekilde ve empati yaparak dinlemenin önemli bir rolünün olduğu düşünülmektedir. Başarılı pazarlama süreçleri ve nihayetinde tatmin edici satışların etkili bir iletişim ve dinlemenin gerçekleştiği ortamlarda sağlanabileceği düşünülmektedir.

\section{Satın Alma Niyeti ve Satın Alma Davranışı}

Niyet, bir şeyi yapmayı önceden isteyerek tasarlama anlamına gelmekte olup herhangi bir davranışı gerçekleştirmeye yönelik fiili iradenin önemli bir göstergesi olarak karşımıza çıkmaktadır (Mutlu vd. 2011, s.55). Niyet, tutum ve davranış ilişkisinde anahtar konumundadır. Niyet kavramını tüketici ve müşteri açısından yorumlamak gerekirse, satın alma alternatiflerini değerlendirme ve satın almanın meydana gelmesi süreçleri arasında meydana geldiğini söylemek yanlış olmayacaktır. Satın alma niyeti, müşterinin bir ürünü ya da hizmeti satın almasına yönelik algısal kanaat düzeyidir (Bergeron, 2004, s.117). Diğer bir deyişle, kişinin bir ürünü ya da hizmeti satın alma eğilimidir. Satın alma niyeti, tüketicinin uyaranlara karşı belirleyici tepkisini ortaya çıkaran en kritik satın alma karar süreci aşamalarından biridir (Tek, 1997, s.215). Tüketicilerin satın alma niyetinin altında ürün, hizmet veya marka seçimi, satın alınacak zaman ve miktarla ilgili bilgiler yatmaktadır. Pazarlamacılar için satın alma niyetinin bilinmesi, tüketicinin neyi satın alacağını önceden anlayabilmenin bir yoludur. Bu nedenle pazarlamacılar sık sık tüketici niyetlerinin ölçülmesine yönelik araştırmalar yapmaktadır. Ayrıca, ilişkisel pazarlama bağlamında değerlendirildiğinde mevcut bir müşteriyi elde tutmanın maliyeti, yeni müşteri elde etmekten daha az olduğundan satın alma niyeti işletmelerin önem verdiği bir konudur (Spreng, Harrel ve Mackoy, 1995, s.16).

Tutum, niyet ve davranış birbirini etkileyen ve çoğunlukla belirli bir düzende oluşan kavramlardır. Fishbein ve Ajzen (1975) niyetin, bir bireyin davranışının en iyi belirleyicisi olduğunu belirtmişler ve davranışın niyet tarafından belirlendiğini ön gören, temelleri sosyal psikoloji alanına dayanan "Sebepli Eylem Teorisi" ni geliştirmişlerdir. Bu teori tutumlar, niyetler ve davranışlar arasındaki ilişkileri daha iyi anlayabilmek için geliştirilmiştir. Teoriye göre Şekil 1'de gösterildiği gibi tutumlar ve öznel normlar niyetin belirleyicileri olmaktadır. Niyet ise davranışın ortaya çıkmasına etki etmektedir. Teoriye göre, bir kişinin belirli bir davranışı, o kişinin davranışsal niyeti ile belirlenmekte ve aynı zamanda davranışsal niyet ise kişinin tutumu ve öznel normu ile belirlenmektedir. Buradan hareketle, Sebepli Eylem Teorisi bir ürün ya da hizmeti satın almaya niyeti, tüketiciyi satın alma davranışına yönlendirebileceği savunmaktadır. Bu aşamada satın alma kararlarında etkisi olduğu düşünülen tüketici satın alma niyetine olumlu ya da olumsuz etki edecek faktörlerin belirlenmesi de önemlidir. Ancak bu teorinin plansız, anlık, alışkanlığa dayalı tarzda satın alma davranışlarını açıklamada yetersiz olduğunu söylemek yanlış olmayacaktır. Çünkü bu tarz satın almalar çoğu zaman bilinçli ya da gönüllü olarak gerçekleşmemektedir. Örneğin, plansız satın alınan bir ürün için çoğu zaman önceden bir niyet yoktur ya da gerçekte tüketicide olumsuz imajı olan bir ürün anlık bir kararla satın alınmış olabileceğinden, bu gibi durumlarda teorinin geçerli olmasını beklemek doğru olmayacaktır. 
Meryem AKOĞLAN KOZAK | Merve DOĞAN

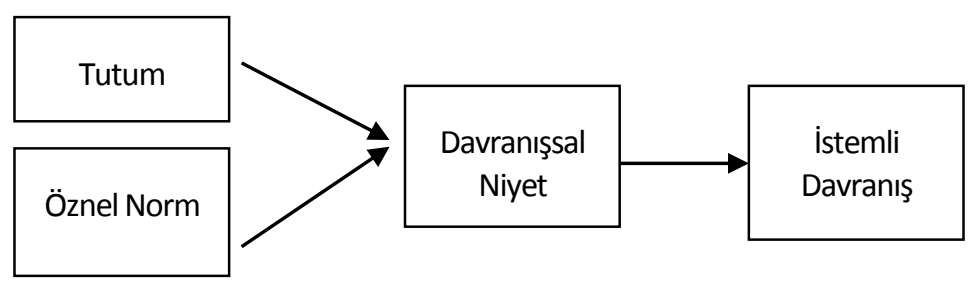

Kaynak: Dillard ve Pfau, (2002)

\section{Şekil 1. Sebepli Eylem Teorisi}

Sosyal, psikolojik, ekonomik ve kişisel birçok faktörden etkilenen satın alma davranışı bireyin kararlarında baskın olan faktörlere göre değişiklik gösterebilmektedir. Bu durum tüketicilerin her türlü alışverişte hep aynı davranışı göstermeyeceklerini düşündürmektedir. Turizm endüstrisinde de turizm ürününün dokunulmayan, eş zamanlı üretim ve tüketim, sahipsizlik, depolanamama gibi özelliklerine ek olarak turizm talebinin bazı tüketici gruplarında kolaylıkla ikame edilebilir olması satın alma davranışı üzerinde etkili olmaktadır (Kozak, 2012, s.224).

Pek çok araştırmacı, satın alma niyeti ve satın alma davranışının birbiriyle pozitif ilişkili kavramlar olduğunu göstermektedir. Bu konunun öncülerinden olan Tobin (1959), satın alma niyeti ve satın alma davranışının pozitif ilişkisini ilk kez ortaya koymuştur. Niyetin davranışa dönüşmesi üzerine bir araştırma yapan Juster (1966), müşterilerin araba satın almaya yönelik niyetlerini inceleyerek, gelecekteki altı ay içerisinde kesinlikle ya da muhtemelen araba satın alacağını iddia eden katılımcıların yarısından fazlası satın alma davranışı gösterdiğini ortaya koymuştur. Bu sonuçtan hareketle araştırma kapsamında Sebepli Eylem Teorisi'nin geçerli olduğunu söylemek mümkündür. Benzer şekilde Morwitz, Johnson ve Schmittlein (1993) müşterilerin niyetlerinin direk olarak satın alma kararlarına etki ettiğini, satın alma niyetinin bir ürünü satın almayı arttırdığını ortaya koymuşlardır.

Satın alma niyetinin, ürün ve hizmetin kalitesi, satışın ve satış temsilcisinin etkinliği, müşterinin satıştan memnuniyeti, müşteri ve satış temsilcisi arasındaki ilişki gibi daha pek çok değişkenden de olumlu ya da olumsuz biçimde etkilendiğini kanıtlar çalışmalar mevcuttur. Örneğin, LaBarbera ve Mazursky (1983), müşterinin satın alma niyetinin müşteri memnuniyetiyle güçlü bir şekilde ilişkili olduğunu belirtmişlerdir. Crosby, Evans ve Cowles (1990) ise satış ilişkilerini ele alarak bir müşterinin gelecekte satış temsilcisiyle tekrar görüşmek istemesinde aralarındaki ilişki kalitesinin önemli bir belirleyici olduğunu ifade etmişlerdir. Bu araştırma kapsamında değerlendirecek olursak, bir satış ilişkisinde taraflar arasında kaliteli ve devamlı ilişki kurulmasında iletişim ve dinlemenin önemi büyüktür. Benzer şekilde Ramsey ve Sohi (1997), bir müşterinin satış temsilcisi ile gelecekteki etkileşim beklentisinin, satış temsilcisinin etkili dinleme yeteneği ile pozitif ilişkili olduğunu ortaya koymuşlardır. Bu çalışmaya paralel olarak Bergeron (2004) de satış temsilcisinin dinleme yeteneklerinin, müşterinin satın alma niyetiyle pozitif biçimde ilişkili olduğunu göstermiştir. Literatürdeki ça- 
Iışmalardan hareketle, müşterinin satın alma niyeti ve bu niyetin davranışa dönüşmesinde, satış ilişkisinde bir diğer taraf olan satış temsilcisinin iletişim ve dinleme becerilerinin belirleyici olabileceği düşünülmektedir.

\section{Araştırma Sorusu ve Hipotezler}

Buraya kadar yapılan değerlendirmelere bağlı olarak turist, potansiyel turist ya da seyahat hizmetlerinden birini satın almış ve bu konuda deneyimi olan müşteri diyebileceğimiz kişi ile satış temsilcisinin dinleme davranışı ilişkisini ele alan turizm sektörünü temsil eden herhangi araştırma bulgusuna rastlanmamış olması bu araştırmanın sorusunun, "Seyahat Acentası Satış Temsilcisinin Aktif Empatik Dinleme Davranışının Satın Alma Niyeti Ve Satın Alma Davranışı Üzerinde Nasıl Bir Etkisi Vardır?"olarak belirlenmesine dayanak oluşturmuştur. Araştırma sonuçlarının turizm literatüründeki bu boşluğa ufak da olsa bir katkı yapması beklenmektedir. Araştırmanın hipotezleri ise aşağıdaki gibi oluşturulmuştur.

$\mathbf{H}_{1}$ : Satış temsilcisinin aktif empatik dinleme davranışı satın alma niyeti üzerinde pozitif yönde istatistiksel olarak anlamlı bir etkiye sahiptir.

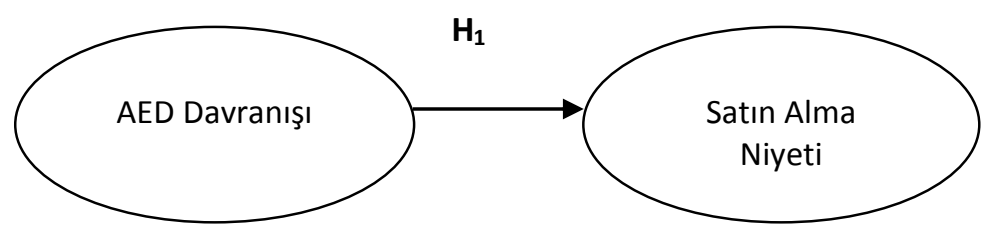

$\mathbf{H}_{1 \mathrm{a}}$ : Satış temsilcisinin aktif empatik dinleme davranışının algılama boyutu satın alma niyeti üzerinde pozitif yönde istatistiksel olarak anlamlı bir etkiye sahiptir.

$\mathbf{H}_{\mathbf{1 b}}$ : Satış temsilcisinin aktif empatik dinleme davranışının işleme boyutu satın alma niyeti üzerinde pozitif yönde istatistiksel olarak anlamlı bir etkiye sahiptir.

$\mathbf{H}_{\mathbf{1 c}}$ : Satış temsilcisinin aktif empatik dinleme davranışının yanıt boyutu satın alma niyeti üzerinde pozitif yönde istatistiksel olarak anlamlı bir etkiye sahiptir.

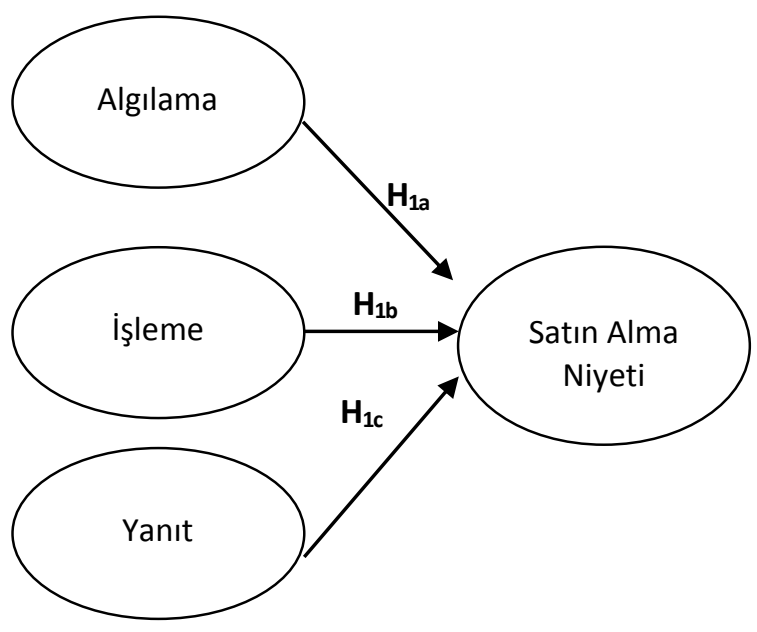




\section{Meryem AKOĞLAN KOZAK | Merve DOĞAN}

$\mathbf{H}_{\mathbf{2}}$ : Satış temsilcisinin aktif empatik dinleme davranışı satın alma davranışı üzerinde pozitif yönde istatistiksel olarak anlamlı bir etkiye sahiptir.

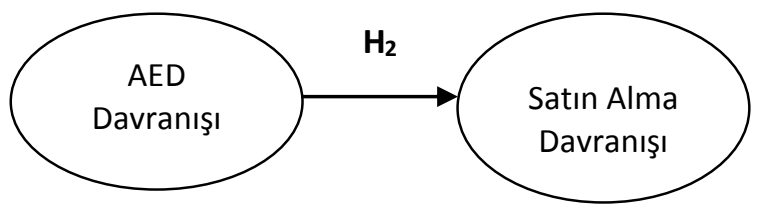

$\mathbf{H}_{2 a}$ : Satış temsilcisinin aktif empatik dinleme davranışının algılama boyutu satın alma davranışı üzerinde pozitif yönde istatistiksel olarak anlamlı bir etkiye sahiptir.

$\mathbf{H}_{2 b}$ : Satış temsilcilerinin aktif empatik dinleme davranışının işleme boyutu satın alma davranışı üzerinde pozitif yönde istatistiksel olarak anlamlı bir etkiye sahiptir.

$\mathbf{H}_{2 c}$ : Satış temsilcisinin aktif empatik dinleme davranışının yanıt boyutu satın alma davranışı üzerinde pozitif yönde istatistiksel olarak anlamlı bir etkiye sahiptir.

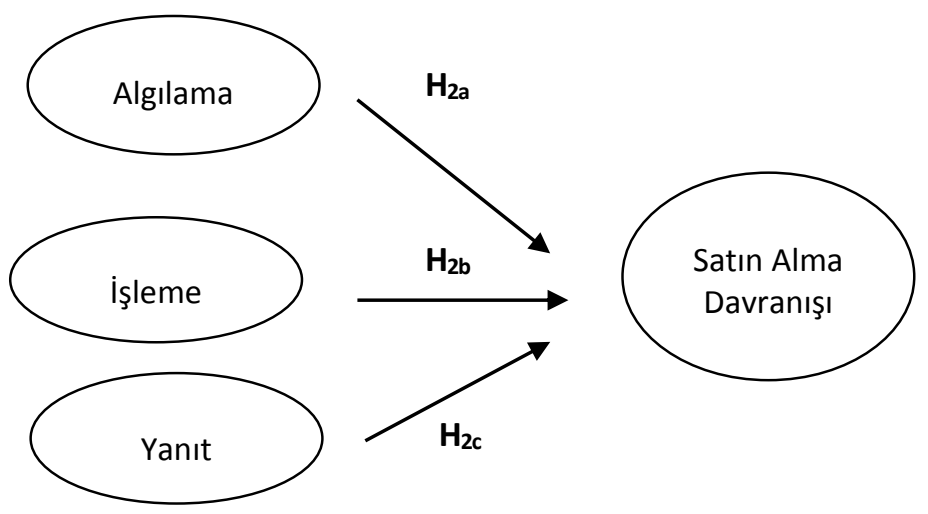

\section{Araştırma Yöntemi}

Önceki bölümlerde açıklanmaya çalışılan gerekçelere bağlı olarak düzenlenen araştırmanın tasarımına bu bölümde yer verilmektedir.

\subsection{Evren ve Örneklem}

Eskişehir il merkezinde ikamet eden 18 yaş ve üzeri bireyler araştırmanın evrenini oluşturmaktadır. Bu araştırmanın verileri kolayda örnekleme yöntemi uygulanarak 14 Aralık 2013 - 8 Ocak 2014 tarihleri arasında anket formu aracılığıla toplanmıştır. Satış temsilcisinin aktif empatik dinle- 
me davranışı ile müşteri satın alma niyeti ve satın alma davranışı arasındaki ilişkiyi incelemek üzere gerçekleştirilen bu çalışma, seyahat acentelerindeki satış temsilcileri bağlamında gerçekleştirilmiş ve çalışmanın verileri daha önce herhangi bir seyahat acentesi satış temsilcisi ile görüşmüş kişilerden elde edilmiştir. Bu sebeple, anket formunu yanıtlayacak kişilerin son 1 yıl içinde herhangi bir seyahat acentesi satış temsilcisi ile görüşüp görüşmediklerini saptamak üzere bir kontrol sorusu eklenmiştir. Bu kontrol sorusuyla satış temsilcisiyle etkileşime geçmiş bireylerin ayrıştırılabileceği ve görüşme yapmış bireylerin algıladıkları aktif empatik dinleme davranışlarının değerlendirilebileceği öngörülmektedir. Veri toplama sürecinde toplam 300 adet anket uygulanmıştır. Ancak anket formunda yer alan kontrol sorusuna 53 katılımc "Hayır" olarak yanıt verdiği için bu anketler analiz dışında tutulmuş ve 247 anket formu analize tabi tutulmuştur.

\subsection{Veri Toplama Yöntemi}

Çalışmada veri toplama aracı olarak anket uygulanmıştır. Veriler yüz yüze görüşme ve bırak-al yöntemleriyle toplanmıştır. Anket formunda ilk olarak bir kontrol sorusuna yer verilmiştir. Kontrol sorusunun amacı, katılımcıların son 1 yıl içinde herhangi bir seyahat acentası satış temsilcisi ile etkileşime geçip geçmediklerini belirlemektir. Kontrol sorusundan sonra, Drollinger vd. (2006) tarafından geliştirilmiş olan "Aktif Empatik Dinleme Ölçeği" ifadelerine yer verilmiştir. Bu ifadelerinin ardından ise katıımıının satış temsilcisiyle geçmişte yapmış olduğu görüşme sonrasında satın alma davranışının ortaya çıkıp çıkmadığını ve gelecekteki satın alma niyetini ölçmeye yönelik olarak oluşturulmuş ifadeler olan "Bu görüşme sonrasında ilgili acenteden herhangi bir tur, tatil vb. satın aldım" ve "Gelecekte tekrar bu acenteden tur, tatil vb. satın alma niyetindeyim" ifadelerine yer verilmiştir. Son olarak da katılımcıların demografik özelliklerini belirlemeye yönelik sorulara yer verilmiştir.

Anket üzerindeki ölçek ifadelerine katılım düzeyi, "Kesinlikle Katılıyorum, Katılıyorum, Ne Katııyorum Ne Katılmıyorum, Katılmıyorum, Kesinlikle Katılmıyorum" şeklinde 5'li Likert derecelendirme ölçeği ile sayısallaştırımıştır. Elde edilen verilerin analizi aşamasında ise SPSS 18.0 programından yararlanılmıştır.

\subsection{Araştırmanın Sınırlılıkları}

Araştırmanın sonuçları araştırma verilerinin toplanmış olduğu süreç ile kısıtıdır. Araştırma bir doktora dersi kapsamında gerçekleştirildiğinden araştırmanın verileri görece kısa bir süre (1 aydan daha az) içerisinde toplanmıştır, dolayısıyla yüksek sayıda katılımcı sayısına ulaşılamamıştır. Öte yandan, araştırmanın katılımcıları ulaşım zorluğundan dolayı belli bir olasılık hesabına dayanmayan kolayda örneklem yöntemi kullanılarak Eskişehir il merkezinde ikamet eden bireylerden seçilmiştir. Bu sebepten dolayı araştırma sonuçlarının tüm bireylere genellenmesi mümkün değildir. Son olarak, katılımcıların verdikleri yanıtlara deneyimlerin hafızalarındaki etkilerinin ya da benzer şekilde hale etkisinden kaynaklı ön yargıların sınırlılık oluşturduğu düşünülmektedir. 
Meryem AKOĞLAN KOZAK | Merve DOĞAN

\section{Bulgular}

Araştırmaya katılan katılımcıların demografik özelliklerine ve betimleyici istatistiksel bilgilerine ilişkin ayrıntılar Tablo 1 ve Tablo 2' de yer almaktadır.

Tablo 1. Katılımcıların Demografik Özellikleri

\begin{tabular}{lrr}
\hline \hline Demografik Özellikler & Frekans & Yüzde \\
Cinsiyet & 152 & \\
Kadın & 95 & 61.5 \\
Erkek & & 38.5 \\
Yaş & 83 & \\
25 ve altı & 130 & 33.6 \\
$26-35$ & 12 & 52.6 \\
$36-45$ & 22 & 4.9 \\
$46-55$ & 0 & 8.9 \\
56 ve üstü & & 0 \\
Aylık Gelir & 35 & \\
750 TL ve altı & 49 & 14.2 \\
751 TL-1500 TL & 81 & 19.8 \\
1501 TL-2500 TL & 82 & 32.8 \\
2501 TL ve üzeri & & 33.2 \\
\hline
\end{tabular}

Katılımcıların demografik özelliklerine Tablo 1' de yer verilmiştir. Bulgulara göre katılımcıların büyük bir kısmını kadınlar oluşturmaktadır. Örneklemi oluşturan katıımcıların yaş aralıklarına göre dağılımlarına bakıldığında, katıımcıların yarıdan fazlasının genç yetişkin yaş grubunda yer aldığı görülmektedir. Bunun sebebinin Türkiye'nin yaşlı nüfus oranının düşük olması ve üçüncü yaş turizminin Türkiye'de hala çok yaygınlaşamamış olduğu düşünülmektedir. Öyle ki, Türkiye İstatistik Kurumu'nun (TUiK) son 3 yıla ait hane halkı turizm istatistikleri incelendiğinde 45 yaş ve üzeri yaş grubu bireylerin seyahat sayılarının, 25-44 yaş grubundaki bireylere göre çok daha az olduğu görülmektedir (http://www.tuik.gov.tr/PreTablo.do?alt_id=1072, Erişim: 13.01.2014). Son olarak katılımcılar gelirlerine göre incelendiğinde, seyahat acenteleri ile görüşmüş kişilerin belirli bir gelir seviyesinin üzerinde ve genellikle Türkiye ortalamasına göre yüksek gelire sahip bireyler olduğu tespit edilmiştir. 
Tablo 2. Betimleyici İstatistikler

\begin{tabular}{|c|c|c|c|c|c|c|c|c|c|c|}
\hline & $\begin{array}{l}\frac{\pi}{\mathfrak{T}} \\
\frac{\pi}{\pi} \\
\stackrel{\pi}{0}\end{array}$ & 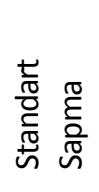 & $\frac{\frac{\text { 产 }}{\overline{\frac{0}{2}}}}{\text { U }}$ & 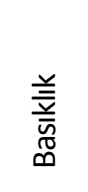 & 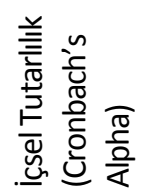 & $\frac{\frac{\pi}{E}}{\frac{\pi}{D}}$ & $\frac{\mathscr{q}}{\underline{\underline{U}}}$ & 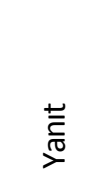 & 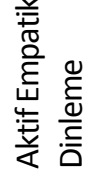 & 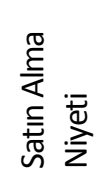 \\
\hline 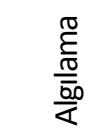 & 3.20 & 0.79 & -0.25 & 0.24 & 0.83 & 1 & & & & \\
\hline 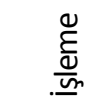 & 3.36 & 0.98 & -0.56 & -0.18 & 0.80 & $0.67^{* *}$ & 1 & & & \\
\hline 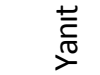 & 3.55 & 0.98 & -0.82 & 0.20 & 0.92 & $0.64^{* *}$ & $0.77^{* *}$ & 1 & & \\
\hline 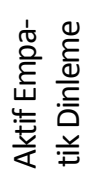 & 3.37 & 0.82 & -0.66 & 0.58 & 0.92 & $0.84^{* *}$ & $0.92^{* *}$ & $0.91^{* *}$ & 1 & \\
\hline 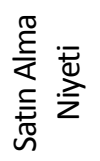 & 3.36 & 1.07 & -0.48 & -0.29 & - & $0.51^{* *}$ & $0.45^{* *}$ & $0.61^{* *}$ & $0.58^{* *}$ & 1 \\
\hline
\end{tabular}

Tablo 2'de görüldüğü üzere, araştırmaya konu olan değişkenlerin ölçümlenmesinde kullanılmış olan ölçeklerin içsel tutarlıık düzeyleri Nunnally (1994) tarafından önerilen 0.70'den yüksektir. Bu bulgu ölçeklerin güvenirliklerinin sağlandığını göstermektedir. Öte yandan, aktif empatik dinleme davranışı ve alt boyutları arasında anlamlı ilişkiler olduğu saptanmıştır. Verilerin normalliğini sınamaya yönelik olarak çarpıklık ve basıklık değerleri tespit edilmiş olup bu değerlerin -1 ile +1 arasında yer aldığı görülmektedir. Dolayısıyla, çalışmanın ilerleyen kısımlarında yapılacak olan analizlerde parametrik analiz tekniklerinin kullanılabileceğini söylemek mümkündür (Çokluk vd. 2012).

Aktif empatik dinleme davranışının faktör yapısının orijinalinde olduğu gibi korunup korunmadığını test etmek adına açıklayıcı faktör analizi uygulanmıştır. Analiz neticesinde KMO değerinin .855 ve istatistiksel olarak anlamlı olduğu tespit edilmiş olup ölçek ifadelerinin faktör analizine 


\section{Meryem AKOĞLAN KOZAK | Merve DOĞAN}

uygunluğunu desteklemiştir. Ayrıca, varimax rotasyon yöntemi ile gerçekleştirilmiş olan faktör analizi neticesinde aktif empatik dinleme davranışının orijinalinde olan üç boyuta ulaşılmış ve toplam açıklanan varyans \%77.488 olarak tespit edilmiştir. Açıklayıcı faktör analizi neticesinde aktif empatik dinleme davranışı ölçeğinin ifadelerinin faktörler bazında dağılımı Tablo 3'de görülmektedir.

Tablo 3. Aktif empatik dinleme davranışının açıklayıcı faktör analizi sonuçları

\begin{tabular}{lccc}
\hline \hline & 1 & 2 & Faktör (Boyut) \\
& 0.836 & & \\
yanit_3 & 0.827 & & \\
yanit_1 & 0.803 & & \\
yanit_4 & 0.795 & 0.796 \\
yanit_2 & & 0.784 \\
algılama_1 & & 0.762 \\
algılama_4 & & 0.737 \\
algılama_3 & & & 0.852 \\
algılama_2 & & & 0.838 \\
işleme_3 & & & 0.784 \\
işleme_1 & & & \\
işleme_2 & & & \\
\hline
\end{tabular}

Tablo 3'de görüldüğü üzere aktif empatik dinleme davranışı ölçeğinin ifadeleri orijinalinde olduğu gibi ait oldukları boyutlara 0.70 üzerinde yüklenmektedirler. İlgili yüklenim düzeyleri Hair vd. (1998) tarafından önerilen kabul sınırları içerisinde yer almaktadır.

Tablo 4'de satış temsilcisinin aktif empatik dinleme davranışının, tüketici satın alma niyeti üzerindeki etkisinin sınandığı regresyon modeline ilişkin bulgulara yer verilmiştir.

Tablo 4. Aktif empatik dinlemenin satın alma niyeti üzerindeki etkisinin sınandığı regresyon modeline ilişkin bulgular

\begin{tabular}{|c|c|c|c|c|c|c|}
\hline & Std. Etki Katsayısı ( $\beta$ ) & $\begin{array}{r}\text { Açıklanan Varyans } \\
\left(R^{2}\right)\end{array}$ & $\begin{array}{r}\text { Düz. Açıklanan } \\
\text { Varyans }\end{array}$ & $\begin{array}{l}\text { Std. } \\
\text { Hata }\end{array}$ & $\mathrm{F}$ & sig. (p) \\
\hline $\begin{array}{l}\text { Aktif empatik dinlemenin } \\
\text { satın alma niyeti üzerin- } \\
\text { deki etkisinin sınandığı } \\
\text { regresyon modeli (lineer } \\
\text { regresyon) }\end{array}$ & 0.589 & 0.347 & 0.344 & 0.872 & 130.209 & $0.001^{*}$ \\
\hline
\end{tabular}


Tablo 4'de görüldüğü üzere, satış temsilcisinin aktif empatik dinleme düzeyinin tüketicinin satın alma niyeti üzerinde 0.589 düzeyinde anlamlı bir etkiye sahip olduğu tespit edilmiştir. Bu bulgu, satış temsilcisinin aktif empatik dinleme düzeyi arttıkça tüketicinin satın alma niyetinde de artış olduğu şeklinde yorumlanabilmektedir. Ayrıca ilgili regresyon modelinin istatistiksel olarak anlamlı olduğu görülmektedir ( $F=130.209 ; p<0.001)$. Modelin istatistiksel olarak anlamlı olması ise regresyon sonucunda elde edilen bulguların istatistiksel olarak anlamlı olduğu çıkarımı sağlamaktadır.

Tablo 5. Aktif empatik dinlemenin boyutlarının satın alma niyeti üzerindeki etkilerinin sınandığı ileriye doğru adım adım (stepwise) regresyon modeline ilişkin bulgular

\begin{tabular}{|c|c|c|c|c|c|c|c|c|c|c|}
\hline & $\mathrm{R}$ & $\mathrm{R}^{2}$ & $\begin{array}{r}\text { Düz. } \\
\mathrm{R}^{2}\end{array}$ & $\begin{array}{l}\text { Std. } \\
\text { hata }\end{array}$ & $\begin{array}{r}\mathrm{R}^{2} \\
\text { değ. }\end{array}$ & $\begin{array}{r}\mathrm{R}^{2} \text { değ. } \\
\text { anlamllığı }\end{array}$ & $\begin{array}{l}\text { Durbin- } \\
\text { Watson }\end{array}$ & Std. $\beta$ & $\begin{array}{r}\text { Std. B } \\
\text { anlamlılığı }\end{array}$ & VIF \\
\hline $\begin{array}{l}\text { Model-1 } \\
\text { Yanit }\end{array}$ & 0.610 & 0.372 & 0.370 & 0.855 & 0.372 & 0.001 & - & 0.610 & 0.001 & 1.000 \\
\hline $\begin{array}{l}\text { Model-2 } \\
\text { Yanit }\end{array}$ & 0.630 & 0.397 & 0.392 & 0.840 & 0.024 & 0.002 & 1.759 & 0.479 & 0.001 & 1.703 \\
\hline $\begin{array}{l}\text { Model-2 } \\
\text { Algilama }\end{array}$ & & & & & & & & 0.204 & 0.002 & 1.703 \\
\hline
\end{tabular}

Tablo 5'de ise aktif empatik dinlemenin algılama, işleme ve yanıt boyutlarının satın alma niyeti üzerindeki görece etkileri ileriye doğru adım adım regresyon yöntemiyle sınanmıştır. İleriye doğru adım adım regresyon (stepwise), bağımsız değişkenlerin bağımlı değişken üzerindeki görece etkilerinin, bağımlı değişken üzerinde görece en büyük istatistiksel olarak anlamlı etkiye sahip bağımsız değişkenden başlayarak istatistiksel olarak anlamlı görece etkiye sahip olmayan değişkene kadar bir dizi regresyon modelinin sınanmasını kapsamaktadır. Nitekim Tablo 5 'de görüldüğü üzere satın alma niyeti üzerinde en yüksek istatistiksel olarak anlamlı etkiye sahip aktif empatik dinleme boyutunun yanıt boyutu olduğu tespit edilmiştir (Std. $\beta=0.610 ; p<0.001$ ). Yanıt boyutundan sonra satın alma niyeti üzerinde en yüksek istatistiksel olarak anlamlı etkiye sahip aktif empatik dinleme boyutunun algılama boyutu olduğu tespit edilmiştir (Std. $\beta=0.204$; $p<0.002$ ). İşleme boyutunun da dâhil edilmiş olduğu regresyon modelinin Tablo 5 'de yer almadığı görülmektedir. Bu durumun sebebi, işleme boyutunun yanıt ve algılama boyutuna ilaveten bağımlı değişken olan satın alma niyeti üzerinde anlamlı bir açıklayıcılığa sahip olmadığından kaynaklanmaktadır.

İleriye doğru adım adım (stepwise) regresyon modeli, bağımsız değişken setinden ilk olarak bağımlı değişken üzerinde en yüksek düzeyde etkili olan bağımsı değişkeni model kapsamına alarak sürece başlamaktadır. Daha sonra modele alınan ilk bağımsız değişkenden sonra hala bağımlı değişken üzerinde anlamlı açıklayıcılığa sahip bir bağımsız değişken varsa onu da modele dâhil etmektedir. Ileriye doğru adım adım (stepwise) regresyon modelinin algoritması bağımlı değişken üzerinde anlamsız olan değişkenler model dışında kalacak şekilde sonlanması üzerinedir. Bu algoritmayı bu çalışma kapsamında açıklamak gerekirse bir diğer deyişle neden işleme boyutunun regresyon tablosunda yer almadığı sorusuna cevap vermek gerekirse; bağımlı değişken olan niyet üzerinde en yüksek açıklayıcılığa sahip bağımsız değişken yanıt olduğu için ilk olarak modele yanıt 


\section{Meryem AKOĞLAN KOZAK | Merve DOĞAN}

boyutu sokulmuştur. Yanıttan sonra bağımsız değişkende açıklanması beklenen arta kalan varyansı algılama boyutu anlamlı bir şekilde açıkladığı için modele ikinci olarak algılama boyutu sokulmuştur. Tablo 5'de işleme boyutunun olmamasının sebebi yanıt ve işlemeden sonra bağımlı değişken niyetin arta kalan varyansını işleme boyutunun anlamlı bir şekilde açıklamamasıdır. Bütün bu işlemler ileriye doğru adım adım (stepwise) regresyon algoritması tarafından otomatik olarak gerçekleştirilmektedir.

Özetlemek gerekirse, satın alma niyeti üzerinde aktif empatik dinleme boyutlarından en yüksek etkiye sahip boyutun yanıt boyutu olduğu daha sonra algılama boyutunun satın alma niyeti üzerinde anlamlı bir etkiye sahip olduğu, işleme boyutunun ise satın alma niyeti üzerinde istatistiksel olarak anlamlı bir etkiye sahip olmadığı görülmüştür. Son olarak, Durbin-Watson değerinin (1.759) 2'ye yakın bir değere sahip olmasından ve VIF değerinin 10'dan epey düşük bir değere sahip olmasından dolayı regresyon analizi sonuçları üzerinde sapmalara neden olabilecek otokorelasyon ve çoklu-bağıntı (multi-collinearity) sorunlarının olmadığı görülmüştür. Bu doğrultuda regresyon analizi çıktıları yansızdır ve yorumlanabilmektedir.

Tablo 6'da, satış temsilcisinin aktif empatik dinleme davranışının tüketici satın alma davranışı üzerindeki etkisinin sınandığı lojistik regresyon modelinin analizi sonucunda elde edilen bulgular yer almaktadır.

Tablo 6. Aktif empatik dinlemenin satın alma davranışı üzerindeki etkinsinin sınandığı lojistik regresyon modeline ilişkin bulgular

\begin{tabular}{lrrrrrrr}
\hline \hline & -2 log likelihood & $\begin{array}{r}\text { Cox \& } \\
\text { Snell } R^{2}\end{array}$ & $\begin{array}{r}\text { Nagelkerke } \\
R^{2}\end{array}$ & $\begin{array}{r}\text { Hosmer \& Lemes- } \\
\text { how }\end{array}$ & Wald & sig. (p) & Exp. ( $\beta$ ) \\
$\begin{array}{l}\text { Aktif } \\
\text { empatik } \\
\text { dinleme }\end{array}$ & 291.254 & 0.185 & 0.247 & 0.001 & 36.134 & $0.001^{*}$ & 0.267 \\
\hline
\end{tabular}

Bu çalışmada satın alma davranışı, $E K^{\prime}$ de yer alan anket formunda da görüleceği gibi dikotomik(kategorik) bir biçimde ölçüldüğü için aktif empatik dinleme ile olan ilişkisini incelemek üzere lojistik regresyon analizinden faydalanılmıştı. Cox ve Snell $R^{2}$ değeri 0.185 , Nagelkerke $R^{2}$ değeri 0.247 olarak tespit edilmiş olup bu değerler bağımsız değişken olan aktif empatik dinlemenin bağımlı değişken olan satın almadaki açıkladığı varyansı belirtmektedir. Bir anlamda Cox ve Snell $R^{2}$ ile Nagelkerke $R^{2}$ değerleri sahte $R^{2}$ değeri olarak da bilinmektedir. Bu durumun sebebi bağımlı değişkenin dikotomik olması ve net bir açıklanan varyans hesabı yapmanın (lineer regresyonda olduğu gibi) mümkün olmamasından kaynaklanmaktadır. Öte yandan, Hosmer ve Lemeshow testinin istatistiksel olarak anlamlı $p<0.001$ ( $p>0.05$ ) tespit edilmesi model-veri uyumunun yeterli düzeyde olmadığını göstermektedir. Fakat Hosmer ve Lemeshow testinin ki-kare uyum iyiliği testi olarak bilinmesinden dolayı bu testin örneklem büyüklüğüne karşı çok hassas olmasının ilgili sonucun elde edilmesine neden olduğu düşünülmektedir (Çokluk vd., 2012).

Tablo 6'da görüldüğü üzere, Wald istatistiği 36.134 olarak tespit edilmiştir. Wald istatistiği $\beta$ katsayııının istatistiksel anlamllı̆ğıı sınayan istatistiktir. Nitekim $\beta$ katsayısı 0.267 olarak tespit 
edilmiş ve katsayının istatistiksel olarak anlamlı olduğu görülmüştür (Wald=36.134; $p<0.001$ ). Bütün bu bulguları özetlemek gerekirse, aktif empatik dinleme düzeyi arttıkça satın alma olasılığının da arttığı çıkarımında bulunulabilmektedir. Çünkü lojistik regresyon modelinde satın alanlar 0 , satın almayanlar 1 olarak kodlanmıştır. Diğer bir deyişle, lojistik regresyon analizinin bulguları, 0'dan 1'e doğru gidildikçe (satın alanlardan satın almayanlara doğru gittikçe) aktif empatik dinlemenin azaldığını ( $\beta$ katsayısı 0.267; 1'den küçük) ortaya koymaktadır. Özetle, satın alma davranışı gösteren tüketicilerle ilgilenen satış temsilcilerinin aktif empatik dinleme düzeylerinin daha yüksek olduğu istatistiksel olarak tespit edilmiştir.

Tablo 7'de ise satış temsilcisinin aktif empatik dinleme davranışının boyutları olan algılama, işleme ve yanıtın, tüketici satın alma davranışı üzerindeki etkisinin sınandığı lojistik regresyon modelinin analizi sonucunda elde edilen bulgular yer almaktadır.

Tablo 7. Aktif empatik dinlenemenin boyutlarının satın alma davranışı üzerindeki etkilerinin sınandığı lojistik regresyon modeline ilişkin bulgular

\begin{tabular}{|c|c|c|c|c|c|c|c|}
\hline & -2 log likelihood & $\begin{array}{r}\text { Cox \& } \\
\text { Snell R² }\end{array}$ & $\begin{array}{r}\text { Nagelkerke } \\
\mathrm{R}^{2}\end{array}$ & $\begin{array}{r}\text { Hosmer \& Le- } \\
\text { meshow }\end{array}$ & Wald & sig. (p) & Exp. ( $\beta)$ \\
\hline Algılama & & & & & 0.104 & 0.747 & 1.086 \\
\hline İşleme & 283.966 & 0.209 & 0.279 & 0.001 & 1.737 & 0.187 & 0.731 \\
\hline Yanit & & & & & 14.670 & $0.001^{*}$ & 0.378 \\
\hline
\end{tabular}

Satın alma davranışı dikotomik (kategorik) bir biçimde ölçüldüğü için lojistik regresyon analizinden faydalanılmıştır. Cox ve Snell $R^{2}$ değeri 0.209 , Nagelkerke $R^{2}$ değeri 0.279 olarak tespit edilmiş olup bu değerler bağımsız değişken olan aktif empatik dinlemenin bağımlı değişken olan satın almadaki açıkladığı varyansı belirtmektedir. Daha önce de belirtildiği gibi bir anlamda Cox ve Snell $R^{2}$ ile Nagelkerke $R^{2}$ değerleri sahte $R^{2}$ değeri olarak da bilinmektedir. Bu durumun sebebi bağımlı değişkenin dikotomik olması ve net bir açıklanan varyans hesabı yapmanın (lineer regresyonda olduğu gibi) mümkün olmamasından kaynaklanmaktadır. Öte yandan, Hosmer ve Lemeshow testinin istatistiksel olarak anlamlı $p<0.001(p>0.05)$ tespit edilmesi model-veri uyumunun yeterli düzeyde olmadığını göstermektedir. Fakat Hosmer ve Lemeshow testinin ki-kare uyum iyiliği testi olarak bilinmesinden dolayı bu testin örneklem büyüklüğüne karşı çok hassas olmasının ilgili sonucun elde edilmesine neden olduğu düşünülmektedir (Çokluk vd., 2012). Aktif empatik dinlemenin boyutlarından sadece "yanıt" boyutunun satın alma davranışı üzerinde anlamlı bir etkiye sahip olduğu tespit edilmiştir (Wald=14.670; $\beta=0.378 ; p<0.001$ ). Bu bulgu doğrultusunda, satış temsilcisinin yanıt düzeyi arttıkça müşterinin satın almama olasılığının azaldığı çıkarımında bulunulabilmektedir. Çünkü lojistik regresyon modelinde satın alanlar 0, satın almayanlar 1 olarak kodlanmıştır. Buradan hareketle, lojistik regresyon analizi bulguları, 0'dan 1'e doğru gittikçe (satın alanlardan satın almayanlara doğru gittikçe) yanıt boyutunun azaldığını (çünkü $\beta$ katsayısı 0.267; 1'den küçük) söylemek mümkün olmaktadır. Diğer bir deyişle, satın alım gerçekleştiren tüketicilerle ilgilenen 


\section{Meryem AKOĞLAN KOZAK | Merve DOĞAN}

satış temsilcilerinin yanıt düzeylerinin daha yüksek olduğu istatistiksel olarak tespit edilmiştir. Öte yandan, aktif empatik dinlemenin alglama (Wald=0.104; $\beta=1.086 ; p=0.747$ ) ve işleme (Wald=1.737; $\beta=0.731 ; p=0.187$ ) boyutlarının satın alma davranışı üzerinde anlamlı bir etkiye sahip olmadığı tespit edilmiştir.

Son olarak Tablo 8'de analiz sonuçlarına göre araştırma hipotezlerinin desteklenip desteklenmediği görülmektedir.

Tablo 8. Araştırma Hipotezleri Analiz Sonuçları

$\mathbf{H}_{\mathbf{1}}$ :Satış temsilcisinin aktif empatik dinleme davranışı satın alma niyeti üzerinde pozitif $\quad$ Desteklendi yönde istatistiksel olarak anlamlı bir etkiye sahiptir.

$\mathrm{H}_{1 \mathrm{a}}$ : Satış temsilcisinin aktif empatik dinleme davranışının algılama boyutu satın alma Desteklendi niyeti üzerinde pozitif yönde istatistiksel olarak anlamlı bir etkiye sahiptir.

$\mathbf{H}_{1 b}$ : Satış temsilcisinin aktif empatik dinleme davranışının işleme boyutu satın alma Desteklenmedi niyeti üzerinde pozitif yönde istatistiksel olarak anlamlı bir etkiye sahiptir.

$\mathbf{H}_{11}$ : Satış temsilcisinin aktif empatik dinleme davranışının yanıt boyutu satın alma Desteklendi niyeti üzerinde pozitif yönde istatistiksel olarak anlamlı bir etkiye sahiptir.

$\mathbf{H}_{2}$ : : Satış temsilcisinin aktif empatik dinleme davranışı satın alma davranışı üzerinde Desteklendi pozitif yönde istatistiksel olarak anlamlı bir etkiye sahiptir.

$\mathbf{H}_{2 a}$ : Satış temsilcisinin aktif empatik dinleme davranışının algılama boyutu satın alma Desteklenmedi davranışı üzerinde pozitif yönde istatistiksel olarak anlamlı bir etkiye sahiptir.

$\mathrm{H}_{2 b}$ : Satış temsilcilerinin aktif empatik dinleme davranışının işleme boyutu satın alma Desteklenmedi davranışı üzerinde pozitif yönde istatistiksel olarak anlamlı bir etkiye sahiptir.

$H_{2 c}$ : : Satış temsilcisinin aktif empatik dinleme davranışının yanıt boyutu satın alma Desteklendi davranışı üzerinde pozitif yönde istatistiksel olarak anlamlı bir etkiye sahiptir.

Bulgulara göre aktif empatik dinleme davranışının satın alma niyeti ve satın alma davranışı üzerinde pozitif yönde etkisi olduğunu varsayan hipotezler $\mathrm{H}_{1}$ ve $\mathrm{H}_{2}$ desteklenmiştir. Ancak aktif empatik dinlemenin her 3 boyutunun da satın alma niyeti ve satın alma davranışı üzerinde pozitif yönde etkili olmadığı görülmüştür. Tablo 8'de görülebileceği gibi satın alma niyeti üzerinde algılama ve yanıt, satın alma davranışı üzerinde ise sadece yanıt boyutunun pozitif anlamlı etkiye sahip olduğu tespit edilmiştir.

\section{Sonuç ve Öneriler}

Illetişimin temel becerilerinden biri olan dinleme, hangi alanda olursa olsun iletişimin etkin bir şekilde gerçekleşmesi, kişilerarası ilişkilerin kurulması ve sürdürülmesinde önemli bir role sahiptir. Bilindiği gibi bir ürün ya da hizmetin satılması ve bunun için yürütülen tüm pazarlama faaliyetlerinde işletme ve tüketiciler arasında etkili bir iletişim sağlanması gereklidir. Bu durumda, tüketici ve işletme arasındaki bağlantıyı sağlayan satış temsilcilerinin sahip oldukları iletişim ve dinleme yete- 
nekleri, işletme ile tüketici arasındaki ilişkilerin kurulması ve devamlılı̆ııın sağlanmasında etkili olabilmektedir. Önceki çalışmalarda bir etkili dinleme türü olan aktif empatik dinlemenin satış bağlamında pek fazla ele alınmadığı göze çarpmaktadır. Literatürde satış bağlamında dinlemeyle ilgili yapılmış çalışmalar incelendiğinde, etkili dinlemenin müşteri güveni ve memnuniyeti, satın alma niyeti, gelecekte tekrar satın alma, satış performansı gibi pek çok satışla ilgili önemli çıktı üzerinde olumlu etkileri olduğu görülmektedir. Tüm bunlardan hareketle satış temsilcisinin aktif empatik dinleme davranışının müşteri satın alma niyetini ve satın alma davranışını olumlu bir şekilde etkileyebileceği düşünülmektedir. Bu doğrultuda kurulan araştırma hipotezleri ve modellerinden yola çıkılarak gerçekleştirilen bu kantitatif araştırmanın sonuçlarına bu bölümde yer verilmiştir.

Sonuçlar etkili dinlemeyle ilgili yapılmış önceki çalışmalarla benzer doğrultuda olup onları desteklemektedir. Sonuçlara göre satış temsilcisinin müşteri tarafından algılanan aktif empatik dinleme davranışı, satın alma niyeti ve satın alma davranışının üzerinde pozitif ve anlamlı bir etkiye sahip olduğu düşünülmektedir. Diğer bir deyişle, bir satış temsilcisinin sahip olduğu aktif empatik dinleme yetenekleri müşterinin satın alma kararlarını olumlu yönde etkileyebilmektedir. Birey etkin bir şekilde dinlenildiğini algıladığında satışa konu olan ürün ya da hizmeti satın alma niyetinde ve satın alma davranışında artış olmaktadır. Çünkü etkin bir dinleme ile müşteri istek ve intiyaçları doğru biçimde anlaşılabilmektedir. İstek ve ihtiyaçları yerine getirilen bireylerin satın alma niyetinde olması ya da satın alma davranışını göstermesi beklenen bir durum olabilmektedir.

Önceki bölümlerde belirtildiği gibi aktif empatik dinlemen algılama, işleme ve yanıt olmak üzere 3 boyutlu bir süreçten meydana gelmektedir. Aktif empatik dinlemeyi oluşturan bu boyutların her birinin satın alma niyeti ve satın alma davranışı üzerinde olumlu etkisi olduğu düşünülmüş ancak araştırma sonuçlarına göre satın alma niyeti üzerinde sadece algılama ve yanıt boyutlarının pozitif yönde anlamlı etkileri olduğu tespit edilmiştir. Dolayısıyla, satın alma niyetinin oluşmasında müşterinin söylediklerinin satış temsilcisi tarafından doğru bir şekilde algılanması ve bunlara uygun yanıtlar vermesi etkili olabilmektedir. Bu çalışmanın örnekleminde yer alan bireyler satış temsilcilerinin mesajları zihinlerinde işledikleri süreçle pek ilgilenmemişlerdir. Satın alma davranışı açısından bakıldığında ise farklı bir sonuç ortaya çıkmıştır. Aktif empatik dinlemenin sadece yanıt boyutu satın alma davranışı üzerinde pozitif ve anlamlı bir etkiye sahip olduğu tespit edilmiştir. Bu sonuçlar seyahat acenteleri ve turizm ürünü satın alan bireyler bağlamındaki satış ilişkileri açısından değerlendirildiğinde, bir turizm ürünü için satın alma niyetinin oluşmasında satış temsilcisinin karşısındaki bireyi algılayışı ve verdiği yanıtlar etkiliyken; satın alma davranışının ortaya çıkmasında ise sadece satış temsilcisinin verdiği yanıtlar etkili olabilmektedir. Kısaca, bireyi satın alma davranışına yönelten istek ve ihtiyaçlarına verilmiş yanıtlardır demek mümkündür. Çalışma kapsamında yorumlanacak olursa, turizm ürünüyle ilgilenen bireyleri satış temsilcisinin verdiği yanıtların satın almaya yönelttiği, diğer bir deyişle, sonuç odaklı olarak satın alma kararı verdikleri söylenebilmektedir. Araştırma sonucunda, sadece yanıtların satın alma davranışının ortaya çıkmasında etkili olduğu tespit edilmiş olsa da şunu hatırlatmak gerekir ki, aktif empatik dinleme algılama, işleme ve yanıttan oluşan bir süreçtir ve bireye verilen yanıtların istek ve ihtiyaçları yerine getirebilmesi için dinleme sürecinin etkin biçimde gerçekleşmiş olması gereklidir. Araştırmacıların da daha önce belirttiği gibi 


\section{Meryem AKOĞLAN KOZAK | Merve DOĞAN}

bir satış temsilcisinin etkili dinleyici olarak algılanabilmesi için dinlemenin tüm boyutları ile meşgul olması gereklidir (Ramsey ve Sohi, 1997). Çünkü satış temsilcisinin doğru biçimde algılamadığı ve zihninde anlamlandırmadığı mesajlara uygun bir yanıt verilmesi mümkün değildir. Ifade ettikleriyle uyumlu yanıtlar alamayan bir tüketicinin de satın alma kararı vermesi beklenmek mantıklı olmayacaktır.

Ayrıca, ortaya çıkan sonuçlar "Sebepli Eylem Teorisi" ile açıklandığında, satış temsilcisinin satı̧̧ temsilcisinin müşteriyi doğru biçimde algılaması ve uygun yanıtlar vermesi, onları ürün ya da hizmetle ilgili satın alma niyetinde olma noktasına getirmektedir. Ancak bireyi satın alma davranı̧̧ı aşamasına geçiren sadece satış temsilcisinin verdiği yanıtlar olmaktadır. Bu durumda aktif empatik dinlemenin yanıt boyutunun bireyi satın alma eylemine geçirmede kritik öneme sahip olduğu düşünülmektedir. Bu çalışmanın ise aktif empatik dinleme davranışı ve satıs temsilcisinin yanıtlarının müşteri satın alma niyetine ve satın alma davranışına olumlu etkileri olduğunu ortaya koyarak bu teoriyi besleyebileceğini söylemek mümkündür.

Pazarlama faaliyetlerinin amacı tüketicileri ilgili ürün ya da hizmetleri satın almaya ikna ederek satın alma davranışına yöneltmektir. Bu araştırma sonuçları tüketicileri ikna etmede önemli rolü olan satış temsilcilerinin sahip olduğu aktif empatik dinleme yeteneklerinin, tüketicilerin satın alma niyetlerinin belirlenmesinde ve satın alma kararı almalarında etkili olduğunu ortaya koymaktadır. Empati yaparak karşısındakileri aktif biçimde dinleme davranışı sergileyen ve sonucunda onların istek ve ihtiyaçlarını yerine getirecek uygun yanıtlar veren satış temsilcileri satış sürecini satışla sonlandırabilmektedir. Hizmetlerin dokunulmazlık, eş zamanlı üretim ve tüketim, heterojenlik gibi özelliklerinden dolayı turizm ürünlerinin satışı ve pazarlanması bir ürününkinden daha fazla ikna etme çabası gerektirmektedir (Kozak, 2012). Ayrıca, turistik talep değişken ve belirsiz olduğundan seyahat acentasındaki satış temsilcilerinin işi daha zor olmaktadır. Neredeyse her tüketici farkı istek ve intiyaçlara sahip olabilmektedir. Fakat etkili iletişim ve aktif empatik dinleme becerileri kazanmış satış temsilcileri tüketicileri anlamada daha başarılı olacağından turizm ürününe yönelik satın alma niyetini ve ortaya çıkan satın alma davranışını arttırabilmektedir. Bu da acentaların mevcut ve potansiyel satışlarını arttırarak işletme performansına olumlu yansıyabilmektedir. Satış yöneticileri ya da çalışanların gelişiminden sorumlu birimler bu etkilerin farkında olmalıdır. Dinleme ve diğer iletişim becerileri öğrenilebilir, öğretilebilir ve geliştirilebilir yetenekler olduğundan, turizm sektöründe satış elemanlarına verilecek kapsamlı eğitim programları ile hem diğer iletişim becerilerinin geliştirilmesi hem de aktif empatik dinlemenin her boyutu göz önüne alınarak dinleme becerilerinin etkin bir biçimde kullanılması sağlanabilmektedir.

Ileride yapılacak çalışmalar için daha fazla katılımcıya ulaşılarak gerçekleştirilmesi önerilebilir. Araştırmanın, evreni temsil gücü daha yüksek olan farklı bir örnekleme yöntemi kullanılarak gerçekleştirilmesi de sonuçların genellenebilirliği açııından faydalı olacaktır. Son olarak ileride yapılacak çalışmalar için farklı dinleme türlerinin, tüketici satın alma niyeti ve satın alma davranışı üzerindeki etkilerinin karşılaştırmalı olarak incelenmesini önermek mümkündür. 


\section{Kaynaklar}

Bellous, J. B. (2001). Considering Empathy Some Preliminary Definition, Erişim: http://www.mcmaster.ca/mjtm/bellous1.htm

Bergeron, J. (2004). Antecedents and Consequences of Salesperson Listening Effectiveness in Buyer-Seller Relationships. The John Molson School of Business, Canada, Doktora Tezi. Erişim: http://spectrum.library.concordia.ca/8117/1/NQ96966.pdf

Bergeron, J. ve Laroche, M. (2009). The Effects of Perceived Salesperson Listening Effectiveness in the Financial Industry. Journal of Financial Services Marketing, 14, 6-25.

Bodie, G.D. (2011). The Active-Empathic Listening Scale (AELS): Conceptualization and Evidence of Validity Within the Interpersonal Domain, Communication Quarterly, 59(3), 277-295.

Boe, J. (2012). Listen While You Work. RISMedia's Real Estate, February, 34-35.

Brody, M. (2001). Listen Up! Do You Really Hear What People are Saying?. The American Salesman, 46(5), 24-25.

Brownell, J. (1985). A Model for Listening Instruction: Management Applications. ABC Bulletin, 48(3), 39-44.

Brownell, J. (1990). Perceptions of Elective Listeners: A Management Study. The Jounud of Business Communication, 27(4), 401-415.

Castleberry, S.B. ve Shepherd, D.C. (1993). Effective Interpersonal Listening and Personal Selling. The Journal of Personal Selling \& Sales Management, 13(1), 35-49.

Comer , L . B. ve Drollinger, T . ( 1999 ). Active Empathetic Listening and Selling Success: A Conceptual Framework. Journal of Personal Selling and Sales Management, 19(1), 15-29.

Crosby, L.A., Evans, K.R. ve Cowles, D. (1990). Relationship Quality in Services Selling: An Interpersonal Influence Perspective. Journal of Marketing, 54, 68-81.

Çokluk, Ö., Şekercioğlu, G., ve Büyüköztürk, Ş. (2012). Sosyal Bilimler liçin Çok Değişkenli SPSS ve LiSREL Uygulamaları. Pegem Akademi Yayıncılık. 2. Baskı.

DiGaetani, J.L. (1980). The Business of Listening. Business Horizons, 23(October), 40-46.

Dillard, J. P. ve Pfau, M. W. (2002). The Persuasion Handbook: Developments in Theory and Practice. Sage Publications.

Dökmen, Ü. (1997). Sanatta ve Günlük Yaşamda Illetişim Çatışmaları ve Empati. 14. Baskı. İstanbul: Sistem.

Drollinger, T., Comer, L.B. ve Warrington,P.T. (2006). Development and Validation of the Active Empathetic Listening Scale. Psychology \& Marketing, 23(2), 161-180. 
Meryem AKOĞLAN KOZAK | Merve DOĞAN

Fishbein, M. ve Ajzen, I. (1975). Belief, Attitude Intention and Behavior: An Introduction to the Theory and Research. Addison. Wesley Publications.

Gross, B. (1982). Listening as Information Processing. Communication Quarterly, 30, 304-307.

Gürel, E. ve Tat, M. (2012). Bir Illetişim Edimi Olarak Dinleme ve Türkçede Bulunan Dinleme Temalı Atasözleri ile Deyimler Üzerine Bir İçerik Analizi. Uluslararası Sosyal Araştırmalar Dergisi, 23(5), 277-297.

Gürüz, D. ve Eğinli, A.T. (2010). Iletişim Becerileri. 2.Baskı. Ankara: Nobel.

Hair, J.F. Jr., Anderson, R.E., Tatham, R.L. ve Black, W.C. (1998). Multivariate Data Analysis. Fifth Edition. Prentice Hall. Upper Saddle River, NJ.

Juster, F.T. (1966). Consumer Buying Intentions and Purchase Probability: An Experiment in Survey Design. Journal of the American Statistical Association, 61, 658-696.

Kozak, M. (2004). Değişim Yönetimi-Otel İşletme Müdürlerinin Değişim Yönetimi ile Ilgili Algılamaları Üzerine Bir Araştırma. Ankara: Detay.

Kozak, N. (2012). Turizm Pazarlaması. 4. Baskı. Ankara: Detay.

LaBarbera, P.A. ve Mazursky, D. (1983). A Longitudinal Assessment of Consumer Satisfaction/Dissatisfaction: The Dynamic Aspect of the Cognitive Process. Journal of Marketing Research, 20(4), 393-404.

Lewis, M. ve Reinsch N.L. (1988). Listening in Organizational Environments. Journal of Business Communication, 25(3), 49-67.

Michael, K. (2000). Listening Skill Saves Time, Increases Effectiveness. The American Salesman, 45(9), 3-8.

Morwitz, V.G., Johnson, E. ve Schmittlein, D. (1993). Does Measuring Intent Change Behavior?. Journal of Consumer Research, 20(1), 46-61.

Mutlu, M.H., Çeviker, A. ve Çirkin, Z. (2011). Tüketici Etnosentrizmi ve Yabancı Ürün Satın Alma Niyeti: Türkiye ve Suriye Üzerine Karşılaştırmalı Analiz. Sosyo Ekonomi, 1, 52-74.

Nunnally, J. C. ve Bernstein, I. H. (1994). Psychological Theory. 3. Edition. Newyork: McGraw-Hill.

Odabaşı, Y. (1997). Satış ve Pazarlamada Müşteri Ilişkileri.İstanbul: Der.

Powell, J.T. (1983). Remarks: Listen Attentively to Solve Employee Problems. Personnel Journal, 62, 580-583.

Ramsey, R. P. ve Sohi, R.S. (1997). Listening to Your Customers: The Impact of Perceived Salesperson Listening Behaviour on Relationship Outcomes. Journal of Academy of Marketing Science, 25(2), 127-137. 
Ruyter, K. ve Wetzels, M.G.M. (2000). The Impact of Perceived Listening Behavior in Voice-toVoice Service Encounter. Journal of Service Research, 2(3), 276-283.

Spreng, R. A. Harrel, G. D. ve Mackoy, R. D. (1995). Service Recovery: Impact on Satisfaction and Intentions. Journal of Services Marketing, 9(1), 15-23.

Tek, Ö.B. (1999). Pazarlama Ilkeleri ve Global Yönetimsel Yaklaşım Türkiye Uygulamaları. 8.Baskı. İstanbul: Beta.

Tobin, J. (1959). On the Predictive Value of Consumer Intentions and Attitudes. The Review of Economics and Statistics, 41(1), 1-11.

Wert, F.V. (1989). Learn to Really Listen. The American Salesman, 34(1), 7-9.

http://www.tuik.gov.tr/PreTablo.do?alt_id=1072, Erişim: 13.01.2014 


\section{Meryem AKOĞLAN KOZAK | Merve DOĞAN}

$E K$

Değerli Katılımcı,

Bu anket formu, doktora dersi kapsamında gerçekleştirilen bir çalışmada yararlanılmak üzere oluşturulmuştur. Bu anketin amacı, turizm acentaları bağlamında satış temsilcilerinin dinleme davranışlarının bireylerin satın alma niyeti ve satın alma davranışı üzerindeki etkilerini incelemektir.

Anket formunda her ifadeye verilecek yanıt "Kesinlikle katılmıyorum - Katılmıyorum - Ne Katılıyorum Ne Katılmıyorum - Katılıyorum - Kesinlikle katılıyorum" şeklinde derecelendirilmiştir. Anket formu aracılı̆ıyla toplanacak veriler tümüyle bilimsel amaçlarla kullanılacak olup raporlamada kişisel bilgilere yer verilmeyecektir. Bu nedenle isminizi yazmanıza gerek yoktur.

Anket formundaki ifadeleri yanıtlarken göstereceğiniz duyarlılık araştırmada toplanan verilerin sağlıklı olmasını sağlayacaktır. Lütfen her maddeyi dikkatlice okuduktan sonra size en uygun gelen seçeneği işaretleyiniz. Katkınız için teşekkür ederiz.

Prof. Dr. Meryem AKOĞLAN KOZAK

Anadolu Üniversitesi

mkozak@anadolu.edu.tr

Merve DOĞAN

Turizm İşletmeciliği Anabilim dalı doktora öğrencisi, Anadolu Üniversitesi

merve_dogan@anadolu.edu.tr

Son 12 ay içinde herhangi bir seyahat acentasındaki satış temsilcisi ile görüştünüz mü?

Evet ( ) Hayır ( )

\begin{tabular}{|l|l|l|l|l|l|}
\hline & $\begin{array}{c}\text { Kesinlikle } \\
\text { Katılıyorum }\end{array}$ & Katılıyorum & $\begin{array}{c}\text { Ne Katılıyo- } \\
\text { rum Ne } \\
\text { Katılmıyorum }\end{array}$ & Katılmıyorum Katılmıyorum \\
\hline $\begin{array}{l}\text { 1.Acentedeki satıs temsilcisi dile } \\
\text { getirmediğim hususlara karşı } \\
\text { hassas davrandı. }\end{array}$ & & & & \\
\hline $\begin{array}{l}\text { 2.Ima ettiğim ancak dile getir- } \\
\text { mediğim hususların farkında } \\
\text { görünüyordu. }\end{array}$ & & & & & \\
\hline 3.Hissettiklerimi anladı. & & & & & \\
\hline $\begin{array}{l}\text { 4.Söylediğim kelimelerden daha } \\
\text { fazlasını dinliyordu. }\end{array}$ & & & & & \\
\hline
\end{tabular}




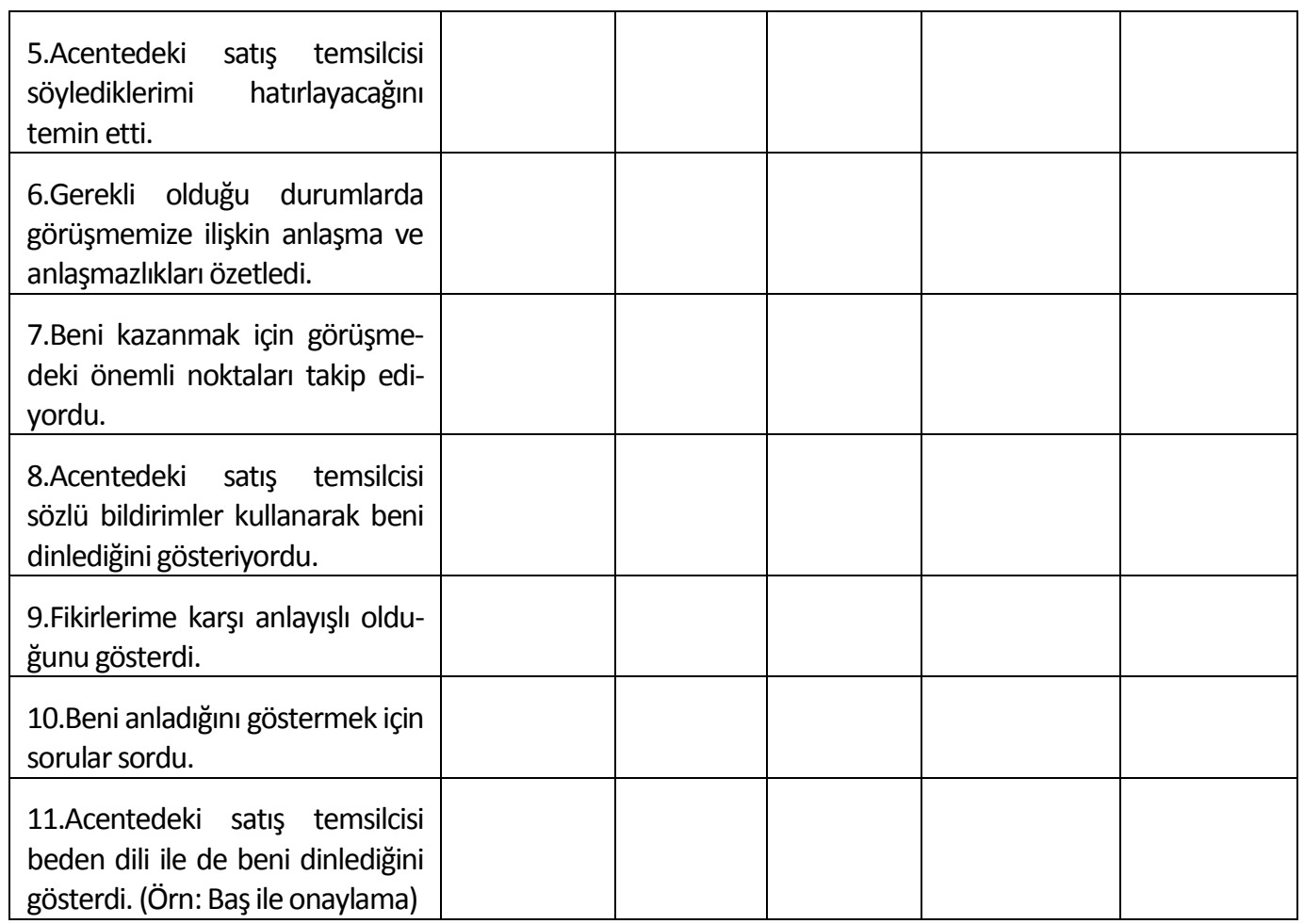

12. Bu görüşme sonrasında ilgili acenteden herhangi bir tur, tatil vb. satın aldım.

\section{( ) Evet ( ) Hayır}

13.Gelecekte tekrar bu acenteden tur, tatil vb. satın alma niyetindeyim.

( ) Kesinlikle Katılmıyorum

( ) Katılmıyorum

( ) Kararsızım

( ) Katıllyorum

( ) Kesinlikle Katılıyorum

Kişisel Bilgiler

\section{Cinsiyet}

( ) Erkek

( ) Kadın
15. Yaş
( ) 25 ve altı
( ) 26-35
( ) $36-45$
( ) 46-55
( ) 56 ve üstü

16. Aylık Gelir (TL)

( ) 750 ve altı

( ) 751 - 1500

( ) $1501-2500$

( ) 2501 ve üzeri 
